\title{
“IT'S JUST NOT RIGHT": THE ETHICS OF INSIDER TRADING
}

\author{
KIM LANE SCHEPPELE*
}

\section{INTRODUCTION}

In his well-known book on insider trading, Henry Manne reported the outraged reaction of "an anonymous lady law student who in a classroom discussion of the subject, stamped her foot and angrily declaimed, 'I don't care; it's just not right."' By putting the ethical argument against insider trading in the mouth of someone so obviously insubstantial by his lights, Manne began the fairly persistent tendency of commentators to address the general morality of insider trading as if it were a fuzzy abstraction, to be swept away easily with more substantial and hard-edged arguments about specific fiduciary duties, general economic efficiency, and property rights in information. ${ }^{2}$ This article attempts to elaborate what the "lady law student" might have meant by saying that insider trading is "just not right." I believe she expressed an important intuition, and this article suggests a rationale for forbidding insider trading, filling out the reasoning behind this intuition.

In the last decade and a half, the Supreme Court has developed a theory of insider trading based primarily on an account of fiduciary duties that securities traders owe to specific others, particularly those with whom they trade and, perhaps, those from whom they receive information. ${ }^{3}$ The United States Court

Copyright $\odot 1993$ by Law and Contemporary Problems

* Arthur F. Thurnau Associate Professor of Political Science and Public Policy, University of Michigan, Ann Arbor; Adjunct Associate Professor of Law, University of Michigan Law School, Ann Arbor.

Much of the research for this paper was conducted while I was the John Rich Faculty Fellow at the Michigan Institute for the Humanities. I would like to thank Roger Rouse for much moral support and for helpful and constructive suggestions, though his help in no way represents agreement with this general approach. I would also like to thank Deborah DeMott, who first suggested I write about this topic and who provided the opportunity and encouragement, Joel Seligman for getting me started in learning the relevant law, Jim Lindgren and Fred Lambert for helping me learn about the more arcane details of the stock market, Cary Coglianese for raising important questions, and Bill Allen for his patient criticism and healthy skepticism about the wisdom of contractarianism.

1. Henry G. MANNE, InSIDER TRAding AND THE StOCK MARKet 233 n.42 (1966).

2. See, e.g., Jonathan R. Macey, From Fairness to Contract: The New Direction of Rules Against Insider Trading, 13 HOFSTRA L. REV. 9, 10 (1984) (describing argument from fairness as "vague and illformed"); see also FRANK EASTERBROOK \& DANIEL FISCHEL, THE ECONOMIC STRUCTURE OF CORPORATE LAW 251 (1991) (chapter entitled Trading on Inside Information, criticizing fairness as an unworkable and unwieldy idea because it has no specific content). Even Loss and Seligman, in their thoughtful review of theories for prohibiting insider trading, collapse arguments about fairness or equity into a purely consequentialist argument about confidence in public markets. LOUIS LOSS \& JOEL SEligman, 7 SECURITIES REgulation 3451-54 (1991).

3. Carpenter v. United States, 484 U.S. 19 (1987); Dirks v. SEC, 463 U.S. 646 (1983); Chiarella v. United States, 445 U.S. 222 (1980). Chiarella and Dirks ground liability primarily in a duty to disclose to existing shareholders from whom stock might be purchased. The dicta in those cases, and the 
of Appeals for the Second Circuit and the United States District Court for the Southern District of New York have not only followed the U.S. Supreme Court's theory of fiduciary duties owed to shareholders, ${ }^{4}$ but the Second Circuit has also developed a broader theory by embracing a prohibition against insider trading based on a misappropriation argument. ${ }^{5}$

Given the general wording of both section 10(b) of the Securities Exchange Act of $1934^{6}$ and Rule 10b-5, courts must bootstrap an interpretation of the law of insider trading up from other general legal concepts, particularly from an analysis of fraud as it has appeared in many different legal contexts. Much of the controversy over the interpretation of Rule $10 \mathrm{~b}-5$ centers on which context for analyzing fraud ought to provide the framework for the analysis of insider trading. This article argues that both the analysis of fiduciary obligations to shareholders and the broader analysis of fiduciary duties to sources of information fail to address the more general ethical problem posed by insider trading: when to require disclosure where the parties to a transaction have

viewpoint in Carpenter that attracted four votes but no opinion, indicate that the Court might be willing to think of securities fraud as fraud on the source of the information, rather than fraud on the holder of the purchased security.

4. See United States v. Chestman (Chestman II), 947 F.2d 551 (2d Cir. 1991), cert. denied, 112 S.Ct. 1759 (1992); Walton v. Morgan Stanley \& Co., Inc., 623 F.2d 796 (2d Cir. 1980); United States v. Willis, 737 F. Supp. 269 (S.D.N.Y. 1990); United States v. Reed, 601 F. Supp. 685 (S.D.N.Y.), rev'd on other grounds, 773 F.2d 477 (2d Cir. 1985). See also SEC v. Texas Gulf Sulphur Co., 401 F.2d 833 (2d Cir. 1968) (en banc), for the Second Circuit's approach before the Supreme Court's decisions in Chiarella and Dirks.

5. Chestman II, 947 F.2d 551; SEC v. Materia, 745 F.2d 197 (2d Cir. 1984); United States v. Newman, 664 F.2d 12 (2d Cir. 1981).

6. Section 10(b) of the Securities and Exchange Act of 1934 provides that:

It shall be unlawful for any person, directly or indirectly, by the use of any means or instrumentality of interstate commerce or of the mails, or of any facility of national securities exchange-

(a) To effect a short sale, or to use or employ any stop-loss order in connection with the purchase or sale, of any security registered on a national securities exchange, in contravention of such rules and regulation as the [Securities and Exchange] Commission may prescribe as necessary or appropriate in the public interest or for the protection of investors.

(b) To use or employ, in connection with the purchase or sale of any security registered on a national securities exchange or any security not so registered, any manipulative or deceptive device or contrivance in contravention of such rules and regulations as the Commission may prescribe as necessary or appropriate in the public interest for the protection of investors.

15 U.S.C. $\$ 78 j$ (1934).

7. Rule $10 \mathrm{~b}-5$ reads as follows:

It shall be unlawful for any person directly or indirectly, by the use of any means or instrumentality of interstate commerce, or of the mails, or of any facility of any national securities exchange, (a) To employ any device, scheme, or artifice to defraud, (b) To make any untrue statement of a material fact or to omit to state a material fact necessary in order to make the statements made, in light of the circumstances under which they were made, not misleading, or (c) To engage in any act, practice, or course of business which operates or would operate as a fraud or deceit upon any person, in connection with the purchase or sale of any security.

17 C.F.R. \& 240.10b-5 (1992). 
asymmetric information. Although specific fiduciary obligations are important to the analysis of insider trading cases, they should be viewed only as partial elements in a more general theory. In my view, a fiduciary relationship creates an obligation not to use any information acquired within the relationship only because such relationships provide privileged access to information.

I will defend an "equal access" approach to the ethics of insider trading. Such an approach has been widely misinterpreted in courts' decisions and academic commentary on insider trading. The Court's majority in the landmark cases of Chiarella $^{8}$ and Dirks $^{9}$ assumes the claim for equal access to information is a claim that the parties to a securities transaction should have equal information, ${ }^{10}$ a proposition that is untenable not only because it is impossibly utopian, but also because fairness does not require equality to extend so far. A theory of equal access to information rewards investment in the production of information in markets and also protects structurally disadvantaged parties in securities transactions. Justice Blackmun, in his dissent in Chiarella, began to elaborate a theory of equal access but stopped short of a full justification of it.

The equal access theory discussed in this article is grounded in contractarian ethics, envisioning fairness as requiring consent to the rules under which benefits and losses are allocated. Unfortunately, discussions of the "fairness" of insider trading have been plagued by charges that fairness is a fuzzy idea that needs to be clarified with the pure logic of economic theory. As a result, conceptions of fairness not rooted in an economic approach have been criticized for failing to provide any clearly defined sense of what would be prohibited. In the last decade or more, the literature on insider trading has been dominated by variations on a stable law-and-economics theme, where the importance of maintaining the efficiency of markets has taken precedence over all other normative claims. In their discussion of insider trading, for example, Frank Easterbrook and Daniel Fischel criticize Justice Blackmun's dissents in Chiarella and Dirks as groping toward a conception of fairness that has no content. They "suspect that few people who invoke arguments on fairness have in mind any particular content for the term. Justice Stewart knew obscenity when he saw it; Justice Blackmun knows unfairness when he sees it. It should be possible, though, to supply a meaning." 11 The goal of this article is to supply content to Justice Blackmun's discussions of fairness by linking fairness to contractarian ethics.

Part II of this article sketches the current Supreme Court doctrine on insider trading, which grounds an obligation to disclose information or refrain from trading in specific fiduciary duties, then argues that this doctrine is incomplete in its historical understanding of what equity has required in similar cases and inadequate in its understanding of modern corporate organization. Part III

8. 445 U.S. 222 (1980).

9. 463 U.S. 646 (1983).

10. See Chiarella, 445 U.S. at 231-235; Dirks, 463 U.S. at 657-59.

11. EASTERBROOK \& FISCHEL, supra note 2, at 251. 
examines the major competing theory of insider trading, the misappropriation theory, which is based on a conception of fraud on the source of information. This article shows how the misappropriation theory fails to consider equitable rules that place limits on the sorts of property claims individuals and corporations could make in information. Part IV develops an alternative theory of the ethics of insider trading, based on a contractarian framework that focuses on the problem of unequal access to information in securities transactions. Part $\mathrm{V}$ examines the ongoing debate about the justifiable limits of insider trading, with special emphasis on the most visible and important recent controversy over insider trading, United States $v$. Chestman. ${ }^{12}$

\section{Fiduciary Obligations and the False SeCURity of Specificity}

As Francis Bacon knew, knowledge is power. ${ }^{13}$ Nowhere does this seem more true than in the securities markets, where the use of special knowledge can lead to tremendous profits. The difficult question, however, is how to decide when special and valuable knowledge becomes an unfair advantage. When does "trading while in the possession of material, nonpublic information"14 become fraud?

Unfortunately, the statutory and regulatory framework generates more questions than guidance. The general language of section 10(b) and Rule 10b-5 does not provide a clear standard for deciding which activities are fraudulent, and does not specify who should be the relevant target of such an inquiry. Under a broad interpretation of Rule 10b-5, any deceptive practice, including silence, that operates in the general neighborhood of a securities transaction, whether committed by the transacting parties or not, might be prohibited. Given the broad potential scope of enforcement, courts have tried to find a way to contain an expansive interpretation of Rule 10b-5. Because violating Rule 10b-5 exposes a person not only to civil penalties in a Securities and Exchange Commission ("SEC") action or through private litigation but also to federal criminal prosecution, it is particularly important to define clear and logical boundaries for the offense of insider trading.

Courts have struggled with the problem of potentially unfair uses of knowledge in securities markets for some time, starting well before the 1934 act was passed. ${ }^{15}$ While the issue was still handled as a matter of judicial cre-

12. 947 F.2d 551 (2d Cir. 1991) (en banc).

13. Francis Bacon, Meditationes Sacrae (1597), reported in John Bartlett, Familiar QUOTATIONS 179 (15th ed. 1980).

14. Loss \& Seligman, supra note 2 , at 3448 . Loss and Seligman argue that this is a better formulation of the problem than "insider trading" because many of those brought into the net in SEC actions against and government prosecutions of traders under Rule 10b-5 are not insiders in the narrow sense.

15. For a brief history of the common law in this area before the 1934 Act was passed, see Loss \& SEligman, supra note 2, at 3466-76. For a longer treatment, see Steve Thel, The Original Conception of Section 10(b) of the Securities Exchange Act, 42 STAN. L. REV. 385 (1990). 
ation, ${ }^{16}$ courts adopted one of three positions on the issue. In many states, corporate insiders, interpreted as including officers and directors, had no affirmative obligation to disclose the information used as a basis for their decisions about securities purchases as long as no harm resulted to the corporation. ${ }^{17}$ Other states viewed officers and directors as having a fiduciary obligation to the existing shareholders to disclose any inside information before buying the stock of the existing shareholders. ${ }^{18}$ A few other jurisdictions developed a compromise between these two extremes, finding an obligation to disclose information only where the particular circumstances revealed that a fiduciary relationship existed between two parties before the sale of securities occurred. $^{19}$

Given the diversity of common law views on the matter, it is not surprising that courts have not interpreted the broad language of the initial regulatory framework uniformly. ${ }^{20}$ Although courts still disagree about the proper grounds for obligations under Rule 10b-5, the Supreme Court's recent analysis in terms of fiduciary obligations to existing shareholders is the most pervasive. ${ }^{21}$ Under the Court's current analysis, traders have no obligation to disclose inside information before using it, absent some specific fiduciary relationship that

16. I use the language of "judicial creation" here to indicate that both equitable and common law concepts were used by judges in this area before statutes fixed the framework at the federal level.

17. See LosS \& SELIGMAN, supra note 2, at 3469-72.

18. Id. at 3472-73.

19. See, e.g., Strong v. Repide, 213 U.S. 419 (1909), discussed in KIM LANE SCHEPPELE, LEGAL SECRETS: EQUALITY AND EFFICIENCY IN THE COMMON LAW 112-15 (1988). In Strong, the buyer of securities from existing shareholders was also the chief negotiator responsible for bargaining in the deal upon which the fortunes of the company rested. The Supreme Court found that had the shareholders known to whom they were selling, they would never have sold their shares because they would have realized that good news from the negotiations was imminent. Because Repide, the negotiator, sent agents out to buy directly from existing shareholders without disclosing his identity, the Court held that the shareholders had been defrauded by being kept in the dark about this material fact. As Henry Manne has pointed out, however, it is not clear that the current Court would find fraud in this case if the trade had gone through an impersonal exchange. See MANNE, supra note 1, at 22.

20. See, for example, the histories offered by Macey, supra note 2, and David Phillips, An Essay: Six Competing Currents of Rule 10b-5 Jurisprudence, 21 IND. L.J. 625 (1988), in which competing justifications of insider trading prosecutions have been offered.

21. The Court anticipated, but did not resolve, one obvious objection to this type of analysis. Grounding insider trading prohibitions in a preexisting relationship between the insider and existing shareholders would mean that an insider trading with material nonpublic information need only abstain from trading or disclosing that information were she buying stock from a current shareholder. If the insider were selling stock, there would be no such general obligation because the buyer would not necessarily be a current shareholder to whom a duty of disclosure would be owed. Justice Powell's opinion for the majority in Chiarella quoted the Securities and Exchange Commission, which in turn, was quoting Judge Learned Hand to the effect that "it would be a sorry distinction to allow him [the trader] to use the advantage of his position to induce the buyer into the position of a beneficiary although he was forbidden to do so once the buyer had become one." Chiarella v. United States, 445 U.S. 222 , 227 $\mathrm{n} .8$ (1980). The opinion then moved on to other issues without indicating whether liability could be grounded in the sale of securities to someone who had no previous connection with the corporation. Typically, insider trading cases involve people buying stocks on the basis of nonpublic information that would lead to an increase in price. In Dirks, however, the Equity Funding scandal caused a massive devaluation in price, so those with whom Dirks shared the information were selling rather than buying. The Court did not think that this made a difference to the analysis, perhaps because Dirks was found to have no fiduciary duty and therefore no liability. 
creates special conditions requiring disclosure. The Court's approach, expressed most clearly in Chiarella ${ }^{22}$ and Dirks, ${ }^{23}$ results in a search for specific sorts of people to whom a duty of disclosure is owed.

In Chiarella, the Court reversed the criminal conviction of a "markup man" who worked for Pandick Press, a financial printer in New York that printed announcements of corporate takeover bids. In the extreme secrecy that attended the preparation for such an announcement, the name of the target company was typically not revealed until the last minute. Chiarella, by carefully studying the announcements before the target company's name was inserted, deduced the identity of the target company in five different deals. He gained more than $\$ 30,000$ in fourteen months by using this information to buy shares of the target corporations so that he could benefit from the price rises when the takeover bids were announced. The SEC caught Chiarella, and he agreed to return his profits to the sellers of the shares. Chiarella was also fired by Pandick. Six months after he disgorged his profits, Chiarella was indicted on criminal charges for violating section 10(b) and Rule 10b-5; at trial, he was convicted on all counts. The Second Circuit affirmed Chiarella's conviction, but the Supreme Court reversed.

Justice Powell, writing for the majority in Chiarella, argued that traders have no general duty to disclose to their trading partners any special information in their possession at the time of the trade absent a specific duty based on a preexisting fiduciary relationship. Claiming that the common law supported this view, Justice Powell explained that any other rule would be untenable because it would subject the possessor of superior information to criminal liability in all transactions in which the parties did not have equal information. Without specific statutory language authorizing such expansion of federal criminal powers, Justice Powell was reluctant to urge a broad construction. Since equal information could not be the rule, Justice Powell saw the primary alternative as narrow disclosure obligations based on existing fiduciary duties.

Justice Powell then began the search for a specific party to whom Chiarella might owe a duty. Chiarella could have no duty to the shareholders of the target company from whom he bought the stock, Justice Powell reasoned, because there had been no prior existing relationship between Chiarella and these shareholders. After all, Chiarella was just a printer, not an officer or director of the target company, parties that might arguably be in such a fiduciary relationship. Although Chiarella might have had a duty to specific people if he had made affirmative misrepresentations to them or told them half-truths while buying their shares, in this case he was merely silent, so no obligation could be found. Alternatively, however, Chiarella might have breached a specific duty to Pandick, his employer, but since that argument had not been presented to the jury, the

22. 445 U.S. $222(1980)$.

23. 463 U.S. 646 (1983). 
Court chose not to address the question. With no specific, preexisting fiduciary relationship on which to pin the duty, the Court reversed Chiarella's conviction.

Justice Blackmun, joined by Justice Marshall, argued in dissent that the conviction should be upheld on a different theory of fiduciary responsibility: the "special facts" doctrine found in cases like Strong v. Repide. ${ }^{24}$ The wrong, wrote Justice Blackmun, was not just in a breach of a preexisting duty, but could also be located in the structural superiority of access to information that Chiarella enjoyed at the expense of his trading partners. Those with whom Chiarella dealt could not know the information that he knew, because he worked in a job that provided him with special information while his trading partners were operating in the dark. If the trading partners wanted to find out this information directly from Pandick, they would have had to break the law to do so. But the illegality of its acquisition made the information no less relevant to their interests. Chiarella, because he worked for the printers through which such information passed, could learn things that others could not and this, Justice Blackmun wrote, was the problem. Emphasizing that fiduciary relationships can grow out of special circumstances in which one person is in a position to rely on the special knowledge of the other in specific transactions, Justice Blackmun argued that cases of structurally asymmetric information typically gave rise to such a "special facts" finding. But these relationships do not necessarily require a long-term preexisting understanding that information will be used in a particular way. Chiarella, to Justice Blackmun, was one of those situations where the very imbalance generated an obligation on the part of the knowledgeable party to disclose the information: "I would hold that persons having access to confidential information that is not legally available to others generally are prohibited by Rule 10b-5 from engaging in schemes to exploit their structural informational advantage through trading in affected securities."25

Though Justice Blackmun endorsed a view much like the one embraced in this article, the majority opinion had a more limited picture of the types of fiduciary obligations that create a duty to disclose. For the majority, duties to disclose information arose only from preexisting fiduciary relationships. The dissent, however, argued that temporary informational imbalances in transactions created fiduciary duties, requiring disclosure.

In Dirks, the court further elaborated the majority's position in Chiarella. Raymond Dirks was an officer in a broker-dealer firm in New York. He specialized in providing investment analyses of insurance companies for institutional investors. In March 1973, he received information from a former officer of Equity Funding of America, a company whose primary business was selling life insurance and mutual funds. Ronald Secrist, the former Equity Funding officer, told Dirks that there was massive fraud occurring inside Equity Funding and that its assets were vastly overrated.

24. Chiarella, 445 U.S. at 245; see discussion, supra note 19.

25. Chiarella, 445 U.S. 222 at 251 (Justice Blackmun, dissenting). 
Dirks flew out to Los Angeles where he interviewed many Equity Funding employees. Though senior management denied the rumors of internal fraud, other employees confirmed Secrist's allegations. After unsuccessfully attempting to persuade the Wall Street Journal to cover the story, Dirks told other investment advisors about the fraud he was uncovering. These advisors then traded the stock in Equity Funding held by their clients. ${ }^{26}$ The price of the stock plummeted, in large part because of the information that Dirks had provided. Two weeks later, the California insurance authorities took action, the SEC began an investigation, and the Wall Street Journal finally published the story. Though Dirks had never owned stock in Equity Funding, nor had his brokerage company traded in the firm, Dirks was charged with insider trading because those to whom he selectively revealed his information had sold early, avoiding the catastrophic losses that occurred when the scandal broke. Tracing the flow of insider information from Secrist through Dirks to the early traders, the SEC argued that Dirks had been a "tippee" of inside information and that he had illegally used it in the market without first publicly disclosing it. Dirks was found guilty of violating section 10 (b) and Rule 10b-5, but was censured, rather than sent to prison or fined, since his investigation had succeeded in uncovering a massive fraud. On appeal, the D.C. Circuit affirmed the conviction, but the Supreme Court again reversed.

In another opinion by Justice Powell, the majority reaffirmed its earlier position: stock transactions in the presence of unequal information may be established as fraudulent only if there is a preexisting duty to disclose based on specific, well-established fiduciary relationships. In this case, Justice Powell argued, Dirks was simply doing what other good analysts would do: research on a company within his scope of specialty. Surely, Justice Powell continued, the courts could not require that investment analysts reveal the results of their investigations before using the information in market transactions.

26. Of course, investment advisors have obligations to their clients to act in their interests, and selling clients' Equity Funding shares on the basis of this dramatic information would have fulfilled such obligations. Should such advisors have also been brought in as defendants in the insider trading case? If one believes the facts as outlined by the majority opinion in this case, then Dirks was engaged in passing on the information about Equity Funding to anyone who would listen, thus lessening the privileged quality of the information. If one believes the facts as outlined in Justice Blackmun's dissent, however, then Dirks was engaged in passing on information to his friends and clients in what looks like a much more selective strategy to benefit himself. In either event, it would be crucial to such a question to work out what the understandings of the other investment advisors were about the circumstances under which they were given this information. By the time this information travelled through this chain of disclosure to reach investment advisors who had no direct connections with Equity Funding, the news might be reasonably thought to be general knowledge. Just when inside knowledge becomes general knowledge poses a sticky problem in the absence of some official announcement of the news. Arguably, in this particular case if one believes the majority's facts, Dirks tried to make a general announcement by interesting the press in covering the story, but when such efforts failed, he passed the information through his own network of investment advisor friends. As Justice Blackmun pointed out in dissent, however, Dirks should have made a general announcement by reporting what he knew to the SEC rather than telling his friends who then dumped Equity shares and got in return "enhanced reputations for looking after their clients." Such conduct by Dirks would have eliminated any question. Dirks v. SEC, 463 U.S. 646, 669 n.4 (1983). 
The problem in this case was more complicated, however, because it involved a tip from an insider. An insider's tip to an outsider might constitute a breach of a fiduciary duty to the corporation and to the shareholders. If the insider violated a specific fiduciary duty by tipping, then the outsider "tippee" might have a derivative duty not to use the information before disclosure, or at all. An insider's tip would violate a fiduciary duty, however, only when the insider disclosed the information in order to gain personally from the corporate information. But since Secrist did not stand to gain personally in disclosing information about the scandal, he did not violate a fiduciary duty by disclosing the information to Dirks, the Court reasoned. Since Secrist had violated no duty, Dirks then could not violate a duty derivatively. The majority argued in dicta, however, that even if Secrist had breached his fiduciary obligations, Dirks could only be held liable on a derivative theory if he knew or had reason to know of Secrist's breach of an obligation not to reveal the information outside the company context.

But once again Justice Blackmun dissented. Beginning with a statement of facts that differed greatly from the statement used to begin the majority's opinion, ${ }^{27}$ he argued that the motivation of personal gain by the insider should not be the determining factor in assessing whether there had been a breach of duty. In this case, Secrist had a duty both to the shareholders, whose investments were on the line, and to the company, as an officer. Giving up the argument about equal access to information that he laid out in his dissent in Chiarella, Justice Blackmun adopted a narrower view of fiduciary duty as resting in preexisting relations of trust and confidence, the very view he criticized the majority for holding in Chiarella.

What is wrong with the theory that only specific fiduciary responsibilities can ground an obligation to disclose information to ignorant trading partners? First, despite Justice Powell's claim that the common law bolsters his argument about the obligation to disclose information, equitable rules invoked by common law courts never supported such a narrow view of the duty in other sorts of transactions. Second, courts understate the crucial role that a wide and dispersed network of economic actors plays in the operation of firms by searching for specific others to whom a duty is owed. As a result, courts place undue emphasis on the search for specific fiduciary duties.

27. Justice Blackmun revealed that Dirks obtained some $\$ 25,000$ in later commissions from those to whom he had revealed the Equity Funding information. Those to whom Dirks told the information sold $\$ 15$ million in stock of Equity Funding, causing the collapse in the price of the stock. Surely, Justice Blackmun argued, Secrist owed an affirmative obligation to shareholders not to reveal information that would destroy their investments. Dirks should count as a participant in the breach by causing the financial collapse. Emphasizing that neither Secrist nor Dirks told the SEC of the fraud so that all investors could be notified, Justice Blackmun portrayed Secrist and Dirks as opportunists, not as the good guys uncovering fraud that Justice Powell's opinion made them out to be. 


\section{A. Looking for Fraud in All The Wrong Places}

Given that Rule $10 \mathrm{~b}-5$ is designed "as a catchall provision, but what it catches must be fraud," 28 Justice Powell's argument in Chiarella rests heavily on his interpretation of what the common law of fraud requires. In his view, "one who fails to disclose material information before the consummation of a transaction commits fraud only when he is under a duty to do so."29 A duty to disclose arises if a secret-keeper induces reliance either through actively misrepresenting the facts or telling half-truths or through violating a fiduciary duty or relationship of trust and confidence. Justice Powell mentions no other duty-generating possibilities that might create an obligation to disclose information. ${ }^{30}$

But courts have often construed equity rules to require disclosure in many situations not involving specific, preexisting fiduciary relationships or active deception. ${ }^{31}$ For example, though the concepts went out of use before the end of the nineteenth century, American courts once used an equitable distinction between intrinsic facts and extrinsic facts in determining when a contract was undermined by a failure to disclose relevant information. Intrinsic facts pertained to "the nature, character, title, safety, use or enjoyment of the subjectmatter [of the contract]; such as natural or artificial defects," 32 and they had to be disclosed if they were not obvious to the seller. Extrinsic facts were "accidentally connected with [the good], rather [than] bear[ing] upon it, at the time of the contract, and may enhance or diminish its value or price, or operate as a motive to make or decline [a] contract." 33 Though this distinction was never very precise, it operated at the core of the Supreme Court's decision in Laidlaw v. Organ. ${ }^{34}$ The Court, in Laidlaw, found no duty for the buyer to disclose information about the signing of the treaty ending the War of 1812 when he purchased a substantial amount of tobacco. Disclosure was not required because the fact in question was extrinsic (that is, about the context of the sale) rather than intrinsic (that is, about the good itself). Although the Court did not explicitly say so in its short, enigmatic opinion, the distinction between intrinsic and extrinsic information could make a difference in this context only if there would be an obligation to disclose intrinsic information-for example, defects in the tobacco itself. This type of obligation would exist only if the distinction could compel disclosure in arm's-length transactions, since the buyer and seller in that case had never before met. In Laidlaw, the Court used the distinction between intrinsic and extrinsic facts in a context where they could not locate a preexisting fiduciary relationship.

\footnotetext{
28. Id. at 235 .

29. Id. at 228 .

30. Id.

31. Much of the discussion that follows draws on SCHEPPELE, supra note 19 (particularly chapter

32. 1 JOSEPH STORY, COMMENTARIES ON EQUITY JURISPRUDENCE AS ADMINISTERED IN ENGLAND AND AMERICA 216-26 (1835).

33. Id. at 210.

34. 15 U.S. (2 Wheat.) 178 (1817).
} 7). 
Though the language of intrinsic and extrinsic facts has since disappeared, courts still require disclosure of hidden defects in goods. The distinction between intrinsic and extrinsic facts has given way to a new distinction, between hidden and obvious defects, that has much the same effect. Obvious defects do not have to be disclosed ${ }^{35}$ since it is assumed that the buyer can discover them as easily as can the seller. Hidden defects, however, must be disclosed even when the parties are dealing at arm's length. Courts have held that parties have a duty, when selling a house, for example, to disclose hidden defects such as unstable soil ${ }^{36}$ defective septic tanks, ${ }^{37}$ and contaminated wells. ${ }^{38}$ Since none of these defects would have been easily discoverable by the purchaser, the seller was held liable for failing to disclose them.

Beyond requiring disclosure of hidden defects, courts also require disclosure of material information in situations where one party has "special confidence" in another. Typically, courts invoke this rule where

\begin{abstract}
there is no existing relationship between the parties, and the transaction is not in its essential nature fiduciary, but it appears that either one or each of the parties, in entering into the contract or other transaction, expressly reposes a trust and confidence in the other; or else from the circumstances of the case, the nature of their dealings, or their positions toward each other, such a trust and confidence in the particular case is necessarily implied. ${ }^{39}$
\end{abstract}

In cases invoking this principle, one party appeared to be taking advantage of an unequal situation by capitalizing on a special vulnerability of the other party. For example, in Barry v. Orahood, ${ }^{40}$ Barry, an agent of the Pure Oil company, bought land from Orahood, who at the time of the sale, was mistakenly believed to be dying. Barry knew that Orahood's land probably had oil under it, but Orahood was not in a position to learn of the ongoing exploration for oil occurring around his property while he was seriously ill. The court found that Barry had an obligation either to refrain from dealing with Orahood while he was ill, or to disclose the information during the negotiations because Barry was in a superior position to discover such information. Courts have used similar rationales, premised on a finding of "undue influence" or the absence of "fair dealing," to justify disclosure in other cases ${ }^{41}$ without requiring a specific, preexisting fiduciary relationship. The duty to disclose arises out of an unequal bargaining position.

Courts have also found that parties have special obligations to disclose information in certain types of transactions, although the parties to the

35. See SCHEPPELE, supra note 19 , at $136-38$.

36. Cohen v. Vivian, 349 P.2d 366 (Col. 1960) (house cracked and sank after purchase).

37. Rich v. Rankl, 269 A.2d 84 (Conn. 1969).

38. Janinda v. Lanning, 390 P.2d. 826 (Idaho 1964).

39. STORY, supra note 32 , at 212 .

40. 132 P.2d 645 (Okla. 1942).

41. See, e.g., Vokes v. Arthur Murray, Inc., 212 So. 2d 906 (Fla. 1968); Chandler v. Butler, 284 S.W.2d 388 (Tex. Ct. App. 1955); and Feist v. Roesler, 86 S.W.2d 787 (Tex. Ct. App. 1935). 
transactions have no preexisting fiduciary relationship. One commentator has described this general family of contracts requiring disclosure as

\begin{abstract}
contracts in the negotiation for which one party must, from the very nature of the transaction, have either actual or presumptive knowledge of circumstances which ordinarily are not within the actual or presumptive knowledge of the other party, and the knowledge of which is, or may be, of importance to that other party to enable him to judge the expediency of entering into the particular contract proposed. ${ }^{42}$
\end{abstract}

Insurance contracts provide the most frequent examples in the case law, because the person trying to acquire the insurance often has knowledge about specific risks that an insurer would not know. ${ }^{43}$ Courts have held that parties seeking insurance have an obligation to disclose relevant information.

All these situations extend the requirements of disclosure beyond the boundaries of preexisting fiduciary relationships. Though the rules in question originated in equity rather than in the common law, they were invoked by common law courts in ordinary contracts cases to find obligations to disclose secrets. The Court, therefore, in analyzing fraud in securities regulation, could draw on this long tradition of invoking equitable rules to broaden disclosure obligations where the statutory language presumed that the standards for fraud would be found elsewhere in the law. As I will argue below, a theory of fairness would require them to do so.

\title{
B. Underestimating Flexible Firms and Impersonal Exchanges
}

One of the big changes in the organization of U.S. corporations in recent years has been described by David Harvey as the move from "Fordism" to a "regime of flexible accumulation." 44 Large, inflexibly organized corporations with stable workforces (Ford-like) have given way to smaller, flexibly organized companies that convert regular wage laborers and formerly salaried managers into independent contractors who can be hired and fired as economic conditions change (flexible accumulation). Firms that once primarily used in-house staffs for their accounting, investing, long-range planning, public relations, legal practice, and even janitorial and production work now increasingly contract out these jobs to independent individuals or firms who provide services only as long as the company needs them. It is becoming increasingly rare for workers or managers to spend the whole of their working lives in the employ of a single company. And with the growth of these new flexible structures, firms find themselves dealing with many different actors, with whom they may have only transient relations, but who need particular and often sensitive information about the firms to be able to work for them. In addition, individuals increasingly find

42. Sir George Spencer Bower, The Law Relating to ACtionable Nondisclosure and OTHER BREACHES OF DUTY IN RELATIONS OF CONFIDENCE AND INFLUENCE 58 (1915).

43. See, e.g., Equitable Life Assurance Society v. McElroy, 83 F. 631 (8th Cir. 1897).

44. David HaRvey, The Condition of Postmodernity 141-72 (1990). 
themselves working on contract for multiple firms over time, or even at once, giving them the ability to compare this sensitive and detailed information across firms to discern subtle differences among them.

As Oliver Williamson has noted, firms do not need to organize themselves hierarchically into large bureaucracies to get work done because a regime of specifically negotiated contracts will perform the same functions more flexibly and, often, at lower cost. ${ }^{45}$ In the realm of economic theory, this organizational structure has long made sense, but in the realm of economic practice, such changes have only recently been enacted so profoundly in a variety of business contexts. Throughout the economy, the boundaries between firms and markets have become more permeable, less constraining, and often invisible. As a result of these changes, it is no longer clear, if indeed it ever was, who is inside and who is outside the modern corporation.

Though the term "insider" does not appear in the statutory language regulating insider trading, there is a powerful sense that rules about fraud pertain especially to people close to the firms whose shares are being traded, and that Rule $10 \mathrm{~b}-5$ regulates the special knowledge acquired by being in such close contact. Objecting to transactions using information gained in this way requires some conception like that of "insider." But who is an insider anymore? In the modern corporation, the distinction between insiders and outsiders is often difficult to draw. Are independent contractors insiders or outsiders? What about employees of contractor companies hired to perform work formerly done by salaried employees of the corporation? Some commentators have tried to alter the definition of an insider so that it better fits the changing world of corporate flexibility, by defining a class of "constructive" or "temporary" insiders. ${ }^{46}$ Others have addressed this problem by changing the focus from looking for insiders to looking for those who possess the material, non-public information that defines the offense. ${ }^{47}$ The Court itself in Dirks announced that it is willing to consider a broader range of actors to be corporate insiders for the purposes of assessing liability for insider trading. Under the Court's analysis, where "corporate information is revealed legitimately to an underwriter, accountant, lawyer, or consultant working for the corporation, these outsiders

45. Oliver Williamson, Markets and Hierarchies, ANAlysis and antitrust IMPlicaTIONS: A STUDY IN THE ECONOMICS OF INTERNAL ORGANIZATION (1975).

46. See SEC v. Ingram, 694 F. Supp. 1437 (C.D. Cal. 1988) for a review of the cases, particularly those criticizing SEC v. Lund, 570 F. Supp. 1397 (C.D. Cal. 1983). The Lund court had a particularly attenuated view of temporary insiders, finding that a friend of an insider who had been told information about the insider's company and then bought stock in it was himself a temporary insider. The court was apparently driven to this description because the insider had not breached a duty in giving information to his friend and so the "fraud on the source" theory could not be invoked. In Ingram, however, the California district court invoked more traditional agency principles and found that a person could become a temporary insider only if he had impliedly or expressly entered into a fiduciary relationship. Thus, Ingram, at a minimum, implied that there must be more than a mere disclosure to activate temporary insider status. $694 \mathrm{~F}$. Supp. at 1440 n.3.

47. Loss \& SELIGMAN, supra note 2, at 3448 . They say explicitly that Rule $10 \mathrm{~b}-5$ applies to people who cannot be defined as insiders, so they would prefer to change the terminology altogether. 
may become fiduciaries of the shareholders" and so inherit the obligations of more conventionally defined insiders. ${ }^{48}$ In order to acquire these obligations, however, the relationship between the temporary insider and the corporation must be negotiated explicitly as a confidential relationship. If the Court is serious about this extension, then its own analysis in Chiarella is in doubt, for surely Pandick Press must have been in some sort of explicitly negotiated relationship of confidence with the companies whose documents they were printing. The Court, however, has not revisited Chiarella nor has it followed up in extending this analysis in its other insider trading cases. As a result, the Court has yet to find someone with such extended relations to have wrongfully engaged in insider trading. The Court's analysis in Dirks as well as in Carpenter ${ }^{49}$ focuses on the Court's narrowest possible basis of obligation: between the employing company and its most directly employed member of the chain of disclosure.

The conception of who is inside and who is outside firms is in flux. But this increased flexibility in modes of economic organization has not been accompanied by actual cases in which such a broader conception of fiduciary duties is found. The particularly narrow focus on specific fiduciary duties shown in cases like Chiarella and Dirks constricts the number of fiduciary relations that produce obligations to disclose at the same time that the knowledge that used to be transmitted primarily in the context of fiduciary relationships is being spread increasingly through more diffuse sorts of social ties. To keep up with changing corporate conditions, courts should view relations of trust and confidence as more contingently defined than they used to be. Despite the Court's recognition of the possibility of such contingent relationships as grounding insider trading claims, the actual pattern of analysis in specific cases has maintained the narrower focus.

Chiarella itself provides an excellent example of the problem. Chiarella was a printer who worked for a company contracted by various other firms to print notices of their takeover bids. Had Chiarella worked in the printshop of the firm about to make the bid, rather than as an employee of a contractor of this firm, he might more easily have been considered an insider. Although not an officer or director of the bidding company or the issuer, he would have arguably had a preexisting fiduciary duty to his employer not to use, for his personal benefit, information that could be used to his employer's detriment. ${ }^{50}$ But his organizational distance from the firms involved in the takeover bids was no doubt responsible for the initial failure to present this argument to the jury at trial.

48. Dirks v. SEC, 463 U.S. 646, 655 n.14 (1983).

49. Carpenter v. United States, 484 U.S. 19 (1987).

50. Former Chief Justice Burger made a similar argument in his dissent in Chiarella, 445 U.S. at 239, but both the majority opinion and Justice Blackmun's dissent argued that this rationale had not been presented explicitly to the jury, and so it would be inappropriate for the Court to uphold a guilty verdict on the basis of an argument that had not been made at trial. But the theory that employees owe a duty to their employers not to use the information gained in the course of employment for personal gain has been developed by the Second Circuit as an element of a theory of misappropriation. See infra part III. 
Even if that argument had been made, however, it is unclear that the majority would have found this relationship sufficiently close and specific to ground criminal liability for insider trading.

In another case involving more distant relations between the alleged defrauder and the securities-issuing firm, Carpenter v. United States, ${ }^{51}$ the Court was asked whether the activities of a Wall Street Journal reporter, R. Foster Winans, could count as insider trading. Winans had used for personal gain information he had gathered in order to write his financial column in the Journal. The Supreme Court did not explore the path that would have connected Winans with the securities-issuing firms in some sort of confidential, or temporaryinsider, relationship through his acquisition of information of the relevant information from the companies on the understanding that he was to use it for his column alone. Instead, the Court chose to cite only the reasoning of the appeals court, whose judgment the Court upheld in a four-to-four vote. The appeals court in this case had noted that the language of Rule 10b-5 specifies that the violation need only be "in connection with" the buying or selling of securities and does not require that the fraud be committed on one of the parties to the securities transaction. So, a fraud against the Wall Street Journal could count as a fraud covered by Rule $10 \mathrm{~b}-5,{ }^{52}$ even though the Journal itself was not engaged in the buying or selling of shares. And Winans could be seen as defrauding the Journal in this light, not the firms whose shares were being traded or the stockholders who bought or sold from Winans. Opting for an analysis that tied Winans very directly to a party that was only indirectly involved in the stock transaction instead of for an analysis that would have tied Winans less directly to a party that was one of the traders, the appeals court reflected the general preference of courts in this area to ground liability in strong ties of a clearly fiduciary character rather than in weaker ties created only for specific instrumental reasons. As the complexity of corporate relations grows, however, the Court may need to extend obligations that come with the acquisition of secrets to the new and distant connections through which knowledge now flows. Fiduciary relationships may need to be as broadly defined in practice as they are now in dicta.

Increased flexibility in corporate organization is not the only structural change in the organization of firms and markets that affects the possibility of finding fiduciary duties. The whole field of securities transactions has become sanitized through the near-universal adoption of exchanges as the medium through which trades occur. As Henry Manne perceptively observed more than two and one-half decades ago, obligations to disclose information have typically been found in cases where buyers and sellers transacted face to face. ${ }^{53}$ Courts generally have not required duties to disclose when buyers and sellers traded

51. 484 U.S. 19 (1987).

52. Id. at 24 .

53. MANNE, supra note 2, ch. 3. 
through impersonal markets, never meeting. ${ }^{54}$ In cases like Strong v. Repide, ${ }^{55}$ where an agent of the buyer bought the shares in question in a face-to-face transaction, and Speed v. Transamerica Corp. ${ }^{56}$ where no stock exchange was implicated either, courts have found duties to disclose to be more extensive than in cases in which the trades are transacted through exchanges. When trading occurs through the anonymity of markets, no preexisting fiduciary relationship exists because no preexisting relationship exists, except in the narrowly defined case of an existing shareholder trading with a corporate insider who has, as a clear duty of his employment, the obligation not to defraud shareholders. But all the other types of activities that used to create an obligation to disclose, activities like actively concealing information, telling half-truths, and taking advantage of a bargainer in a weak condition, no longer seem to create obligations in an impersonal market where buyers and sellers rarely meet. In the anonymous market, buyers and sellers do not engage in face-to-face discussion about why they are buying and selling in the first place. In fact, at the time of the sale, buyers and sellers do not know each other's identities, so they could not have explicitly negotiated prior agreements about how they are to conduct their business, nor would they have had the opportunity to create obligations during the particular transaction. ${ }^{57}$ In sanitized markets, buyers and sellers are not present as concrete individuals with complex particular understandings about the terms of the sale; they are abstracted entities who respond only to the terms of the market-price predominantly, but also whatever information they can find before they trade. The very medium of the stock exchange operates against the creation of specific obligations to disclose information through interaction with one's trading partner.

The development of anonymous markets, though far less recent than the move to flexible modes of corporate organization, presents much the same problem as the structural change does. When the whole structure of corporate organization and finance is moving toward flexibility and anonymity, courts will, not surprisingly, rarely find fraud in securities transactions if they are looking for regular and permanent relationships. The social processes just described make generalized exchange norms and long strings of connection between buyer and seller far more common than specifically negotiated contracts and direct buyerseller trades. But the courts have not kept up with the times by insisting on oldfashioned, specific fiduciary relationships.

54. Id.

55. 213 U.S. 419 (1909)

56. 99 F. Supp. 808 (D. Del. 1951).

57. In the Insider Trading and Securities Fraud Act of 1988, 102 Stat. 4677 (1988), private rights of action were explicitly extended to all traders whose deals were made contemporaneously with an inside trade. The contemporaneous trader can sue an inside trader even if it cannot be demonstrated that the contemporaneous trader bought her stocks from or sold her stocks to the defendant in question. See Donald C. LANGeVOORT, INSIDER TRADING: Regulation, ENFORCEMENT AND PREVENTION ch. 9 (1991), for an explication of the new statute and its reach. 
In many ways, the current structural insensitivity of insider trading rules is like the nineteenth-century common law problem presented by privity of contract. $^{58}$ Before tort law expanded to fill the gap and privity rules were abolished, liability for defective products failed to track changes in the complexity of manufacturing that the nineteenth century witnessed. ${ }^{59}$ In the early part of the nineteenth century, contracts of sale typically involved two parties, one of whom was the initial producer or longstanding holder of a good while the other was the final holder or consumer of a good. Sellers could typically be counted on to know a great deal about the goods that they were selling, and buyers could be counted on to know the final purposes for which the goods would be used. But as industrial manufacturing grew and advances in transportation allowed many goods to be transported far from the places where they were produced, the direct seller's knowledge could no longer be presumed. Increasingly, throughout the nineteenth century, goods produced by one person or company would be sold through several middlemen before arriving at the final purchaser. If the good was defective when the last purchaser bought it, the last purchaser had a permissible suit only against the person with whom he had an explicit contract; the person who had directly sold the good to him. Since the person with whom he had contracted often bought the good simply to sell it again, the seller had little knowledge about the specific qualities of the good, and the loss remained with the purchaser under the rule of caveat emptor. Courts were reluctant to find sellers liable when these sellers had no way of knowing just what was wrong with the things they bought and sold.

The gradual undermining of privity rules, most spectacularly through the rise of tort liability, ${ }^{60}$ eventually allowed legal doctrine to follow the changes in the broader structuring of the economy. In the years between the time that the economic changes took place and the time that the law caught up with them, however, many defective goods were sold on the market. ${ }^{61}$

In the contemporary debates over insider trading, broader structural changes in the economy that separate the holders of privileged access to information from direct relationships with those who may be hurt by the manipulations of secret information are not adequately represented in the doctrine of specific fiduciary duties. This is very similar to the situation in which broader structural changes in the nineteenth century economy did not produce corresponding legal changes because they were blocked by the doctrine of privity of contract. But just as the rise of tort law allowed the increasing attenuation of market relations to be reflected in an expanded conception of legal liability, so too should a generaliza-

58. Brian Simpson argues that privity of contract was largely an invention of the nineteenth century, rather than being a holdover of another age. See A.W. BRIAN SIMPSON, A HISTORY OF THE COMMON LAW OF CONTRACT: THE RISE OF THE ACTION OF ASSUMPSIT 475-85 (1975).

59. This argument is drawn from SCHEPPELE, supra note 19, at 267-98.

60. See, e.g., Grant Gilmore, The Death OF Contract (1974).

61. For the historical evidence, see SCHEPPELE, supra note 19, particularly at 294-95. 
tion of the equitable conception of duties of disclosure be recommended to reflect the changing world of securities transactions. ${ }^{62}$

An expanded conception of equitable duties of disclosure should still have clear boundaries, especially considering the fact that insider trading is subject to criminal as well as civil sanctions. This article argues for such an expanded, but clearly delimited, conception of equitable obligations primarily on the terrain of moral philosophy. In Part IV, I will show why a contractarian ethical theory ought to be credible as a source of normative argument in the law and what a contractarian argument would require in this area. First, however, I will examinë the primary alternate theory to insider trading, the misappropriation theory.

\section{III}

\section{FRAUD ON THE SOURCE AND THE MISAPPROPRIATION OF CORPORATE KNOWLEDGE}

While the Supreme Court's narrow application of the specific fiduciary theory seems to be shrinking what will count as insider trading, the Second Circuit has been developing a powerful new theory that covers a wider array of possible perpetrators in a wider array of situations. The misappropriation theory begins from the premise that material, nonpublic information may count as property possessed by a firm which is entrusted to employees and contractors under the condition that the information be used only for corporate purposes. Any use of this information for personal gain, whether by agents of the firm or confidantes of such agents, or even thieves, should count as fraud. ${ }^{63}$ The misappropriation theory can be grounded in one of two ways. ${ }^{64}$ First, appropriating the information for personal gain counts as fraud on the source of that information and, as such, is fraud "in connection with the purchase or sale of any security"65 within the meaning of rule $10 \mathrm{~b}-5$. Second, if information has been stolen, the thief acquires a duty to the marketplace to disclose it, and trading on such information counts as fraud.

Though a majority of the Supreme Court has yet to endorse the misappropriation theory, the Second Circuit has found some support for its approach in the

62. In most other areas of law, disclosure obligations are already broader than they are in the insider trading case. Expanding disclosure requirements here would bring insider trading law into line with the analysis of fraud in ordinary contracts.

63. In the misappropriation theory, insider trading is an offense against property, involving the conversion of property entrusted for corporate purposes to use for personal gain. This contrasts with the theory proposed in footnote 14 of Dirks, in which liability for insider trading would be premised on a breach of trust in a confidential relationship, where the violation consists in breaking a promise. At the margins, these two arguments may merge in the common worry that employment relationships give rise to expectations about the trustworthiness of employees, expectations that are undermined when an employee either uses corporate knowledge for personal gain or violates an agreement.

64. Both theories were forwarded in the Brief for the United States in Chiarella, cited in LANGEVOORT, supra note $57,86.02 \mathrm{nn} .3,4$.

65. 17 C.F.R. \& 240.10.b-5 (1992). 
opinions of individual justices. ${ }^{66}$ Justice Stevens found the first argument attractive in his concurrence in Chiarella, saying that a defendant might have owed a duty of silence to those from whom he got the information. But Justice Stevens agreed that the theory had not been squarely presented at trial and so could not be the basis for upholding a criminal conviction on appeal. ${ }^{67}$ Chief Justice Burger argued in favor of the other version of the misappropriation theory in his dissent in Chiarella. ${ }^{68}$ Quoting from Keeton's 1936 article on fraud and nondisclosure in sales contracts, Chief Justice Burger emphasized that the means the secret-keeper used to acquire the information in the first place were crucially important in assessing the duty to disclose. ${ }^{69}$ When the secret-keeper acquired the knowledge through an illegal act, the secret then had to be revealed to those with whom the secret-keeper was about to trade, even though there may have been no prior duty to disclose the information if it were lawfully obtained. $^{70}$ Since Chiarella's employer had an explicit policy against Pandick employees using information acquired on the job for personal benefit, Chiarella's use of such information for personal gain constituted misappropriation and trading on it counted as fraud against other investors under Rule 10b-5. As Chief Justice Burger concluded, Chiarella "misappropriated-stole to put it bluntly-valuable nonpublic information entrusted to him in the utmost confidence." 11 On this argument, then, Chiarella's conviction should have been upheld because the theft of information created obligations to fellow traders in the marketplace.

The Second Circuit detailed the misappropriation theory in a series of decisions following Chiarella, though the court clearly leaned more toward the "fraud on the source" theory than toward the "duty to disclose from illegal possession" theory. In United States v. Newman, ${ }^{72}$ the Second Circuit heard the appeal of a man who had been indicted for securities fraud for first allegedly trading on information he received from friends who worked for Morgan Stanley and Kuhn Loeb, and then sharing the resulting profits with those friends. The "connivers in this case," as Judge van Graafeiland called them, ${ }^{73}$ had converted for personal gain information from Morgan Stanley and Kuhn Loeb, and such "deceitful misappropriation of confidential information by a fiduciary"74 could legitimately result in a conviction. The sources of such information (Morgan

66. In Carpenter v. United States, 484 U.S. 19 (1987), the Court upheld in an evenly split ruling the $10 \mathrm{~b}-5$ conviction of a Wall Street Journal columnist. Something like the misappropriation theory that underwrote the Second Circuit decision must have gotten four votes, but the opinion provided no reasoning.

67. Chiarella v. United States, 445 U.S. 222, 237 (1980) (Stevens, J., concurring).

68. Id. at 239 (Burger, C.J., dissenting).

69. Id. at 240 (quoting W. Page Keeton, Fraud-Concealment and Nondisclosure, 13 TEX. L. REV. 1 (1936)).

70. Id.

71. Id. at 245 .

72. 664 F.2d 12 (2d Cir.), cert. denied, 464 U.S. 863 (1981).

73. Id. at 17.

74. Id. at 18 . 
Stanley and Kuhn Loeb) had been defrauded, the court reasoned, and Newman had been part of the scheme by those who were entrusted with the information to defraud the companies through misappropriation. The court upheld the legal sufficiency of the indictment on the prosecution's factual allegations.

In $S E C$ v. Materia, ${ }^{75}$ the Second Circuit confronted a situation factually similar to the one in Chiarella. Anthony Materia worked for a financial printer, Bowne of New York City, and he guessed the takeover targets of bids whose printing was being done by his firm. Upholding an injunction against Materia and an order to disgorge nearly $\$ 100,000$ in profits, Judge Irving Kaufman used the "fraud on the source" misappropriation theory, likening Materia's actions to the actions of an employee who used corporate funds for personal benefit. ${ }^{76}$ But, disagreeing with Chief Justice Burger's dissent in Chiarella, Judge Kaufman explicitly rejected the argument that such misappropriation gave rise to a duty to other investors to disclose the information. Instead, he argued that the fraud was on the source of the information (namely Bowne), and not on the persons with whom such a knowledgeable trader would deal (existing shareholders). For Judge Kaufman, the essence of the offense under the misappropriation theory was the use of the information for personal purposes in violation of a preexisting fiduciary duty to an employer, ${ }^{77}$ an offense that would not have been lessened (and arguably could have been aggravated) by disclosing it to those with whom the secret-keeper traded. $^{78}$

The misappropriation theory was further explicated in United States $v$. Reed ${ }^{79}$ on a motion to dismiss charges of fraud on the source. The facts alleged in the indictment centered on Thomas Reed, who bought and sold call options of Amax, Inc., during the winter of 1981. His father, Gordon Reed, was on the board of directors of Amax and was chairman of the Amax Petroleum Corporation, a wholly owned subsidiary. Immediately before Thomas bought the Amax call options, he learned from his father, in confidence, that Amax was about to be merged into Standard Oil Company of California (Socal), which already owned about twenty percent of Amax stock. Anticipating an increase in the price of Amax shares as a result of this merger, Thomas purchased the call options and waited for the news to be made public. Amax decided not to support the Socal offer, but the price of Amax stock shot up when that news was

75. 745 F.2d 197 (2d Cir. 1984).

76. Id. at 201-02.

77. Id. at 203.

78. In fact, one could argue that disclosing the information would only compound the offense. For one thing, Bowne Printers could be even further damaged by word spreading widely that one of its employees was trading on secret information and that Bowne therefore could not be trusted to keep secrets. Perhaps more crucially, Materia's disclosure before the takeover was accomplished might have the effect of making these deals impossible to complete. If Materia traded alone and secretly, then there would not be a general run-up in prices to match the impending bid. If Materia disclosed to the market before the purchase, the prices would immediately adjust, perhaps increasing the cost of the bid that would be necessary to close the deal.

79. 601 F. Supp. 685 (S.D.N.Y.), rev'd on other grounds, 773 F.2d 477 (2d Cir. 1985). 
made public. Thomas sold his options two days after he bought them, making $\$ 431,000$ on the deal.

The theory the prosecution advanced in Reed was a variant of the "fraud on the source" misappropriation argument. But unlike previous cases where an employee was alleged to have breached a fiduciary obligation to his employer, Reed involved a son who had arguably breached a fiduciary obligation to his father. The prosecution did not allege that Gordon Reed had breached an obligation to Amax in telling his son the news, because father and son often shared business information in confidence as part of their relationship of trust. But that fiduciary relationship between father and son obligated the son not to use the information for his personal gain, in the prosecution's view.

The court reviewed the alternative theories of insider trading liability, finding that Thomas Reed was not liable because he was not himself a corporate insider. Nor was Thomas a tippee liable under the Dirks rationale because his father, who was an insider, had not breached any obligation in discussing the matter with him. Instead, the court argued that someone who receives information from an insider in confidence can be criminally liable if he misappropriates that information for personal gain. The origins of this sort of liability can be found in the doctrine of constructive trust, the court wrote, because someone who receives information in a confidential or fiduciary relationship is obligated to hold the proceeds of any misappropriation of that knowledge in constructive trust for the benefit of the person who initially disclosed the information. ${ }^{80}$

So, the crucial question was: Did father and son have a preexisting fiduciary relationship? Since the concept of a confidential relationship was "born and reared in equity" and "is by nature flexible and defiant of precise definition," case-by-case evaluation alone could answer this question in the light of general principles, according to the court. In his detailed and scholarly review of the principles underlying fiduciary relationships in equity, Judge Robert Ward reviewed the evidence that a confidential relationship might exist between father and son for one of two reasons: (1) where there has been reliance (one party places trust and confidence in another with the encouraged expectation that the other party will keep the confidence $)^{82}$ or (2) where there is de facto control by a superior over an inferior (a disparity in position between the two parties creates a dependency of one upon the other) ${ }^{83}$ If a confidential relationship existed, matters shared between the two parties could not be used to the detriment of the one or for the personal gain of the other. But kinship, by itself, would not create a fiduciary relationship, absent some showing of an actual practice of trusting. ${ }^{84}$ What mattered for finding a confidential relationship, Judge Ward wrote, is a reciprocal agreement in which one person's practice of

\footnotetext{
80. Id. at 700 .

81. Id. at 701 .

82. Id. at $706-07$.

83. Id. at 708 .

84. Id. at $712-14$.
} 
entrusting secrets is met with express or implied consent, or with encouragement, from the person in whom the trust was reposed. Confidential relationships could not be unilaterally imposed, but had to grow from a mutual sense of trust. The government would have to prove a confidential relationship based on such a mutual sense of trust to show that Thomas Reed had committed fraud on his father by using the information about the Socal merger.

Once cases like Reed showed that the fiduciary rationale could be divorced from the employment context, its expansion into other sorts of confidential disclosures was inevitable. In United States $v$. Willis, ${ }^{85}$ the psychiatrist of a woman whose husband was in line to become CEO of BankAmerica if a takeover bid succeeded traded on information about the impending takeover gained through the woman's therapy sessions. On a motion to dismiss, the trial court found that the government could argue that Dr. Willis had breached a confidential relationship. "It is difficult to imagine a relationship that requires a higher degree of trust and confidence than the traditional relationship of doctor and patient," Judge Cedarbaum wrote, finding that Dr. Willis had represented through his agreement to treat Mrs. Weill that he would keep her confidences to himself. ${ }^{86}$ Dr. Willis argued that he had not breached any responsibility to a market participant and, as a result, had not violated insider trading laws. But the court, using the misappropriation theory, held that this was a distinction without a difference.

The Second Circuit's misappropriation theory has broadened the range of people covered by insider trading prohibitions. For this reason, the misappropriation theory avoids the criticisms of narrowness and failure to track reality that I levelled against the fiduciary theory. ${ }^{87}$ But the misappropriation theory has problems of its own. First, the cases that ground the duty not to trade on secret information in the employment relationship rely on an expansive conception of corporate property, one that threatens to deprive employees of any reasonable claim on the contents of their own minds. Trade secret law has confronted this problem and has drawn the line on corporate property somewhere quite different, ${ }^{88}$ for good reasons that should also apply in the insider trading area. Second, in nonemployment relationships, the government, either through an SEC enforcement action or through federal criminal prosecution, is punishing a breach of trust that the alleged victim would be disinclined at best to enforce. The securities laws on such a theory then become a means of coercion for the parties in intimate relationships in ways that punish more than the party engaged in insider trading and that use intimate relationships as springboards for federal criminal prosecution. If the person whose confidence has been breached wants to enforce these claims, there are tort mechanisms to do so. But unlike in tort law claims of breach of confidence, where disclosing secrets leads at most to

85. 737 F. Supp. 269 (S.D.N.Y. 1990).

86. Id. at 272.

87. See supra part II.B.

88. See infra part III.A. 
damages against the breacher, the inside trader context involves potential criminal penalties, not just for the person who trades on inside information, but also for the person who revealed the information in the first place. I will take each of these problems in turn.

\section{A. Whose Mind is it, Anyway?}

One need not put in eighty-hour work weeks to know that the contents of one's job often account for a substantial part of the contents of one's mind. People learn all sorts of things when they work in firms, from office political intrigue to interesting industry gossip to valuable proprietary information. Any of this knowledge might make a difference in securities markets if it affects how that company or some other is run. At the very least, it would be difficult to specify in advance just how to separate information that is likely to have a substantial effect on securities markets from information that is unlikely to have such an effect when all that information is mixed up together in the workplace.

Information that may affect securities is, in this way, very different from the information that constitutes a protectable trade secret. With trade secrets, a company's profits may depend crucially on information kept from competitors about how a company's goods or services are produced. But information subject to trade secret protection must be subject to careful procedures within the workplace for protecting it; otherwise, it may not count as a protectable trade secret. ${ }^{89}$ With insider trading, however, even office politics and other information not traditionally the subject of trade secrets, if located at the right levels among the right people, could make a big difference to the value of the securities of that company or of some other company. Such information, however, is not always cordoned off by special procedures from general knowledge available within the office.

Under the misappropriation theory as it has been developed by the Second Circuit, the use or communication that results in use of any material information learned in the course of employment can potentially expose the discloser to civil or criminal sanctions. Positing a fiduciary relationship between an employee and his firm can allow the employer to use insider trading rules to block disclosure or use by the employee of any material information learned in the course of employment about any publicly traded company. The firm could sue the employee under the private right of action introduced with the 1988 Insider Trading and Securities Fraud Enforcement Act $^{90}$-or the firm could turn the employee over either to the SEC for a civil suit or to the Justice Department for criminal prosecution.

89. In trade secret cases where the firm in question has not made special efforts to keep secrets confined within the company, courts have been reluctant to find enough secrecy to enable the firm to enforce trade secrecy protection. Contrast, e.g., Kodekey Electronics v. Mechanex Corp., 486 F.2d 449 (10th Cir. 1973), with Crown Industries v. Kawneer Co., 335 F. Supp. 749 (N.D. Ill. 1971).

90. 102 Stat. 4677 (1988). 
Seen this way, the reach of the misappropriation theory is broad indeed. If it can be established that the employment relationship alone can be the basis for fiduciary claims that the employee keep all market-sensitive information learned in the course of employment secret as an obligation to the employer, insider trading law might be able to accomplish something other areas of employment law have never been allowed to-extensive control by employers over the contents and uses of employees' minds. And, as former Vice President Dan Quayle once said, "What a waste it is to lose one's mind."91

Courts do not seem to appreciate the practical difficulty in sorting out the information employees must treat with special care from the information they can disclose at will. The relevant formulation used in the employee misappropriation cases is "entrusting." Knowledge is said to be "entrusted" to an employee in the course of the fiduciary relationship of employment. But much knowledge that an employee acquires in working for a company may not be "entrusted" in any specific way at all. It could be learned as a by-product of working on other projects around the office; it could even be generated by the employee himself as part of his own work-product. ${ }^{92}$ The information need not be about the company for whom the employee works, as Carpenter, Newman, and Materia, in particular, reveal. ${ }^{93} \mathrm{~A}$ vast array of potentially market-sensitive information swirls around workplaces without having the crucially important bits singled out for special treatment as the "entrusted" formulation implies. Is no information acquired by an employee in the course of his job usable in the stock market without risk of insider trading charges under a misappropriation theory? Can an employee be held liable to his employer for disclosing market-relevant information in a setting where those to whom he discloses have no obligation to keep the information secret? If courts are looking to define clear boundaries around the offense of insider trading, this is no way to do it.

Courts have addressed a similar problem in the trade secret context. In trade secret cases, an employer sues a current or former employee for divulging, typically to a competitor, information alleged to be a trade secret of the employer. But not just any information can count as a trade secret. For information to be the subject of protection as a trade secret, it must be both secret and the result of a significant investment on the part of the secret-keeping firm. ${ }^{94}$ The secrecy provision requires that the information be singled out

91. Editors of THE Quayle Quarterly, What a Waste It Is To Lose ONE'S Mind: THe UNAUTHORIZED AUTOBIOGRAPHY OF DAN QUAYLE (1992).

92. I am using "he" and "him" throughout this article to refer to inside traders not out of a rejection of feminist inclinations in the use of pronouns but to call special attention to the fact that almost all the inside traders are men. Though information may pass through a woman to get to the man who then trades, women are seriously underrepresented as perpetrators of this offense.

93. In fact, the misappropriation theory is most likely to be used in cases where the information is not about the company for which the employee works because that particular situation would be more safely handled doctrinally by the "fraud on the shareholder" theory espoused by the Supreme Court in Chiarella.

94. For a more detailed analysis of these cases, see SCHEPPELE, supra note 19, at 231-65. 
within the workplace for special attention. ${ }^{95}$ The investment element is crucial in limiting the reach of trade secret law into the minds of employees, since only those bits of knowledge that have resulted from serious acquisition effort are covered. The investment and secrecy requirements serve to limit employees' trade secret liability to a small and relatively clear-cut set of subjects that are more likely to have been explicitly "entrusted" to an employee, or at least made explicitly confidential.

Even with this limited set of items, however, there are some sticky problems in determining when trade secret protections interfere with crucial interests of the employee-for example, the ability of the employee to move on to another firm in the same line of work. If an employee must not disclose anything learned in the course of employment, he may not find it possible to get another job in the same field or to continue to practice his skills. In Continental Car-Na-Var Corp. v. Moseley ${ }^{96}$ and Ridley v. Krout, ${ }^{97}$ courts held that employers could not restrict the uses of former employees' general knowledge of chemistry in the one case and bicycle repair in the other, though specific applications developed in secret at substantial expense by the secret-keeping companies could not leave with the employee. Narrowly carving out the knowledge that could be maintained as a trade secret, the Car-Na-Var court found in equity "the right inherent in all people ... to follow any of the common occupations of life. ... Every individual possesses as a form of property, the right to pursue any calling, business or profession he may choose." If an employer could claim an employee's general knowledge as the property of the employer, the employee would literally have little to work with. Courts will not allow the property claims of employers to interfere with such important rights of employees.

In the insider trading context, it is evident that the secrecy claims of companies under the misappropriation theory can be quite broad, and can quickly run afoul of the limits developed in trade secret cases. Potentially secret knowledge is not limited to production processes or secrets of manufacturing, but ranges across all knowledge that may be acquired in the workplace. Companies can now exert control over their employees in ways that have been denied them by trade secret law; they can claim that any disclosure of information that has an effect on stock prices, whether of their own firm or any other, represents the breach of a confidential relationship. Much of the problem here may be with a broad definition of "materiality," but the company can use the breadth of this definition to control its employees in many potentially objectionable ways. The company need not claim much damage; since damage in insider trading cases is notoriously difficult to demonstrate,${ }^{99}$ courts have backed off from requiring a

95. See infra part III.B for cases that reveal the power of this distinction.

96. 24 Cal. 2d 104, 148 P.2d 9 (1944).

97. 63 Wyo. 252, 180 P.2d 124 (1947).

98. Car-Na-Var, 148 P.2d at 12-13.

99. See, e.g., Jill E. Fisch, Start Making Sense: An Analysis and Proposal for Insider Trading Regulation, 26 GA. L. REV. 179, 195-96 (1991). 
showing of serious harm as an element of an insider trading claim. The injury does not have to be actual, only "threatened." 100 In fact, in most cases, the primary harm alleged is the prospect of "sullying" the reputation of the employing company for keeping secrets. ${ }^{101}$ Virtually anything the company thinks is important enough to sue over probably sullied its reputation. The only harm that has to be demonstrated is that the company thought the disclosure was that serious. ${ }^{102}$

Grounding liability on an employee's failure to keep secret information learned on the job can have disastrous side effects on employment relations. With insider trading law on its side, corporations may be able to use misappropriation theory to claim knowledge that evades the protection of trade secret law as legally protectable corporate property. Corporations may also be able to restrict the flow of knowledge that passes from their employees to others, even in employees' discussions with their friends and family. If the employment relationship is held to be inherently fiduciary and to cover all market-sensitive knowledge learned on the job, working for any company is likely to entail a sort of vigilance outside work that requires an employee never to leave work obligations behind. And this is an enormous intrusion, especially when it is backed up with possible criminal sanctions for any disclosure of work-related information.

\section{B. The Misappropriation of Intimate Relationships by the Government}

As the misappropriation theory spreads out into other areas, such as family relationships, friendship networks, and professional-client pacts, whole webs of people trying to build intimate relationships by sharing information with each other ${ }^{103}$ may be threatened by one wrong move by one partner in a shared secret. Since liability may attach not only to the person using knowledge for a devious purpose, but potentially to people who have entrusted each other with secrets down the line, the misappropriation theory might wreak havoc with intimate relationships everywhere, as indeed it already has in at least one case. ${ }^{104}$ Even if the liability itself does not spread backwards through networks of tippers and tippees, cases brought by the SEC and federal prosecutors must rely for their enforcement of insider trading rules on a breach of confidence to a party who probably does not want to see a friend, relative, or loved one pay huge fines or go to jail.

People already have some protection against the spread of the confidences they entrust to others in confidential relationships by the "public disclosure of

100. See LANGEVOORT, supra note $55, \$ 6.02$.

101. U.S. v. Newman, 664 F.2d 12, 17-18 (2d Cir. 1981), cert. denied, 464 U.S. 868 (1982).

102. In fact, the lawsuit may serve to publicize the company's inability to keep secrets and so could be damaging in itself.

103. See SCHEPPELE, supra note 19, at 303-04, for a discussion of the ways in which shared secrets build solidarity in intimate relationships.

104. See the discussion of Chestman II, 947 F.2d 551, 555 (2d Cir., 1991) (en banc), infra part V. 
private facts" privacy tort. ${ }^{105}$. But current tort protection differs significantly from the sort of liability that the Second Circuit has constructed with its misappropriation theory. First, if someone to whom a secret is disclosed has used that secret to trade in securities, both the tipper and the tippee might be found guilty under Rule 10b-5. The liability of the tipper in insider trading cases would probably be limited by the Dirks requirement that the tipper benefit personally from the transaction, even under the misappropriation theory. But, as Professor Langevoort noted, the Dirks court "felt it necessary to extend the meaning of benefit to cases where the insider was seeking to enhance his reputation by conveying the information, or to gain the 'warm glow' that comes from charitably giving tips to acquaintances or friends." 106 If a person discloses potentially material nonpublic information to friends, relatives, or professionals in return for the warm glow of approval or even from the impulses to benefit from friendship, it could leave the discloser open to criminal prosecution if the friend or relative uses the information in an unauthorized way. ${ }^{107}$

Rule 10b-5 liability differs substantially from the protection accorded confidential relationships under the privacy tort. In public disclosure of private facts cases, only the person who has done the disclosing would be liable because the person whose secret was being passed on would be the plaintiff. The person who initiated the confidence is not held responsible for what is later done with the information passed on and no one else can press the interests of the tipper in the privacy context except the tipper himself. ${ }^{108}$

Second, under the misappropriation doctrine, the Securities and Exchange Commission or federal prosecutors could decide to bring a legal action against a trader on the grounds that he breached the trust of a friend or relative and used information obtained through that relationship for personal gain. Friends or relatives may be the last people to want to see their loved one prosecuted, especially not in their names. In Reed, for example, it is extremely unlikely that Thomas's father wanted his son to go to jail for breaching his confidence, which is, after all, what the misappropriation theory is all about.

In tort cases, since the suit must be brought by the person whose confidences have been betrayed, legal action must grow out of the severance of a relationship. Intact friendship and intact family relationships are unlikely to give rise to these lawsuits. ${ }^{109}$ But the insider trading cases can proceed on the basis of a breach of trust in a relationship that is still intact. The coercion and pressure of

105. See William L. Prosser, Privacy, 48 CAL. L. ReV. 383 (1960), for the influential division of a morass of privacy cases into four neat subcategories. Public disclosure of private facts is one such category. This tort has certain important limitations, however, most relevantly the limitation imposed by the requirement that disclosure of private facts be to more than one or even a few people.

106. LANGEVOORT, supra note $57, \$ 4.02$.

107. See, e.g., the discussion of Chestman II, 947 F.2d 551 (2d Cir. 1991), infra part V.

108. Privacy actions are purely personal actions that die with the claimant and cannot be pressed by others. See, e.g., Von Thodorovich v. Franz Josef Beneficial Ass'n, 154 F. 911 (E.D. Pa. 1907).

109. Since law is the means of last resort for resolving disputes for most people, courts would only see cases where other means of resolution had broken down, along with the relationships in question. 
the lawsuit is then likely to be felt not only by the inside trader, but also by those whose confidence provided the basis for the suit.

The use of misappropriation theory to reach cases where there has been a breach of confidence in an intimate relationship is clearly coercive in those situations where the person who originally disclosed the information to the person who later used it does not want to press charges. The wrong, if any, is to the persons with whom the knowledgeable trader traded, not to those whose interests are allegedly being protected as sources under this theory. But that is not the basis of the misappropriation theory. As we will see, there is a better theory that still allows for prosecutions of people using information that can be traced directly to a structurally superior source. But that theory relies on a violation of duties owed to trading partners and not to those from whom the information was obtained. It will be relevant to trace, however, just where the information came from as a way of establishing the privileged access to information possessed by a putative inside trader. We will see how this works in detail in the next Part.

IV

\section{A Contractarian ARgument for Prohibiting Insider Trading}

Arguments about ethics as "fairness" seem to have fallen on hard times in legal theory of late. The law and economics firestorm that has swept through many areas of doctrine has hit particularly hard in the area of business regulation, where efficiency rhetoric has always been strongest. As a result of the influence of law and economics, arguments about the desirability of legal rules in general, and rules about insider trading specifically, now tend to be couched in consequentialist terms. ${ }^{110}$ Utilitarianism, the moral theory that underwrites the law and economics perspective, involves weighing the net (or total or average) good (or happiness or wealth) of an action against the equivalent value of another action to see which produces the most desirable results. Only the results matter in such a comparison, according to the fundamental premises of utilitarian logic, and the highest value wins the ethical game. One legal rule is argued to be more desirable than another because it will produce better consequences overall than another, and in the law and economics view, the specification of consequences is generally limited to the economic results that would be produced from following one rule rather than another. Ethics, in the world of law and economics, just is simply the comparison of the

110. In the insider trading literature alone, see JONATHAN R. MACEY, INSIDER TRADING: ECONOMICS, Politics AND POLICY (1991); MANNE, supra note 1; Frank H. Easterbrook, Insider Trading as an Agency Problem, in PRINCIPLes AND Agents: THe STRUCtURe of Business 81 (J. Pratt \& R. Zeckhauser eds., 1985); Daniel R. Fischel, Insider Trading and Investment Analysts: An Economic View of Dirks v. Securities and Exchange Commission, 13 HoFSTRA L. REV. 127 (1984); Dennis W. Cariton and Daniel R. Fischel, The Regulation of Insider Trading, 35 STAN. L. REV. 857 (1983); Frank H. Easterbrook, Insider Trading, Secret Agents, Evidentiary Privileges, and the Production of Information, 1981 SUP. CT. REV. 309. 
overall consequences of one rule against another. Any other conception of ethics seems "vague and ill-formed," according to one influential commentator who is committed to the law and economics worldview. ${ }^{111}$

But are other conceptions of ethics that the law might adopt so "vague and ill-formed" that they offer no help to the analyst trying to determine why a business practice may seem to be "just not right"? I will argue that an alternative conception of ethics has a strong resonance in American law and also provides concrete guidance in working out how to think about the ethics of insider trading. Such a contractarian theory provides fairer, more intuitively pleasing results.

Surely one of the major contributions of American jurisprudence among the world's legal systems has been the invention of a written constitution formally declaring that government should operate with the consent of the governed. Such a constitution prefigures its commitment to consent by establishing itself through a ratification process involving a large segment of the citizenry as well as by requiring a supermajoritarian process for amending the document. ${ }^{112}$ At the most basic level of American law, then, the explicit consent of very large and crosscutting majorities is necessary to establish basic rules of the constitutional order.

In addition, because the American Constitution is not just a document detailing the structure of government, but one that also creates enforceable legal claims of rights, the commitment to consent can be seen as especially strong in the American tradition. Rights, in Ronald Dworkin's famous formulation, act as "trumps" in legal argument. ${ }^{113}$ Because a person's consent cannot be overridden except under very special circumstances, the individual who possesses a right has the ability to block efforts to undermine or bypass her consent over the range the right covers. The conception of consent that the American Constitution stands for, then, is the strong version that requires the consent of each individual for laws to be legitimate in areas where she has the protection of rights. Rights cannot be obliterated or argued away in the name of other values like efficiency, ${ }^{114}$ or even moral correctness. ${ }^{115}$ The primary way in

111. Macey, supra note 2, at 15 .

112. For accounts of the constitutional amendment process that bypass the Article V procedures, see Sanford Levinson, Accounting for Constitutional Change (Or, How Many Times Has the United States Constitution Been Amended? (a) <26; (b) 26; (c) >26; (d) All of the Above), 8 CONST. COMMENTARY 409 (1991), and BRUCE ACKERMAN, We THE PEOPLE: Foundations (1991). If one believes that the Supreme Court is fundamentally a democratic institution responding to a broader picture of the consent of the governed, then the supermajoritarianism guaranteed by the formal Article $V$ amendment procedures is not necessary to establish the claim that amendments rely on consent.

113. Ronald Dworkin, Rights as Trumps, in THEORIES OF RIGHTS 153 (Jeremy Waldron ed., 1984).

114. Efficiency as a value is generally associated with utilitarianism. The original exponent of utilitarianism, Jeremy Bentham, was an ardent opponent of rights. See Jeremy Bentham, Anarchical Fallacies; Being an Examination of the Declarations of Rights Issued during The French Revolution, in 2 THE WORKS OF JEREMY BENTHAM 489, 501 (John Bowring ed., 1843) (in which he denounces the idea of natural rights as "simple nonsense" and the idea of "natural and imprescrible rights" as "nonsense upon stilts"). For a modern exponent of the view that utilitarianism and rights are incompatible, see, for example, David Lyons, Utility and Rights, in THEORIES OF RIGHTS 110 (Jeremy Waldron, ed., 1984). 
which a right can lose its ability to block intrusions upon an individual is if the individual consents to the intrusion. ${ }^{116}$ The enormous moral force of consent is still visible throughout the criminal law, where consent to an action by one party is crucial in assessing the legality of the action by another. Consent converts theft to borrowing, rape to lawful sex. Consent has this force in American legal doctrine because a contractualist picture of the legitimacy of law runs deeply throughout American jurisprudence. In any account of the ethics that underlie American law, then, the commitment to consent must be central.

In moral philosophy, a commitment to consent is generally expressed through contractarian political and moral theories. Originating most persuasively in the Anglo-American tradition in the work of John Locke and ideas about the social contract, ${ }^{117}$ consent theory sees the legitimacy of government arising out of the consent of the governed, much as the legitimacy of a contract arises out of the consent of its constitutive parties. The contract metaphor, with free and equal individuals agreeing in advance to be bound by rules that they have explicitly negotiated, provides the basis for contractarian thinking and much of its normative power. For the metaphor to be successful, however, both the conditions under which individuals consent to government and the laws produced by that government must be free of coercion, and it is in the specification of these underlying conditions of consent that various contractarian theories have diverged. Modern contractarians like John Rawls ${ }^{118}$ and David Gauthier ${ }^{119}$ disagree over how to construct the precise conditions in which consent is to be sought, though they agree on the need to ground such decisions in the rational choices of individuals. In the specific argument constructed below, I take yet another tack, arguing that consent to legal rules, in the context of the American systems, must be based on more detailed and contextualized knowledge of specific features of American life and of particular individuals than either Rawls or Gauthier would support. Suffice it for now to say that contractarian arguments, in general, typically evaluate legal regimes and laws based on what potential consenters would say were they asked for their views under conditions that ensured they were free from coercion and other contaminating influences.

115. See, e.g., Jeremy Waldron, A Right to Do Wrong, 92 ETHICs 21 (1981).

116. A more complicated question, and one beyond the scope of the present article, is what to do when rights conflict. There, the logic of the problem would seem to dictate that one right can trump another, but such a specialized problem should not disguise the general pattern that the possession of a right gives its holder the ability to block all those who have less important claims.

117. JOHN LOCKE, TwO TREATISES OF GOVERNMENT (C.B. Macpherson ed. 1988 [1690]). But see also THOMAS HoBBES, LEVIATHAN (C.B. Macpherson ed. 1968 [1651]), for a much less attractive picture of consent. Hobbes argued that in the brutal world of the state of nature, individuals would find it in their interest to come together and give up their freedom for the privilege of living under the certainty, safety, and potential tyranny of an autocratic ruler. Consent for Hobbes is given only once, and it can never be retracted, not even by successive generations. Though Locke, too, sees consent as a more thoroughgoing and non-retractable process than modern readers would approve, at least Locke's theory had the advantage of grounding a representative form of government that would avoid some of the harshness of Hobbes's sovereign.

118. JOHN RAWLS, A THEORY OF JUSTICE (1971).

119. DaVid GaUTHIER, MORALS BY AGREEMENT (1986). 
A consent-based picture of the morality of law generates quite different results from the consequentialist picture of morality that the law and economics school invokes. In that utilitarian world, only the economic results of alternative legal rules matter in assessing the moral desirability of the rules. In the contractarian world, the legitimacy of a law is assessed by examining the integrity of the process that produced the law in the first place. If one adopts a contractarian view, law ${ }^{120}$ acquires its legitimacy from its procedural pedigree. If laws are enacted in agreed-upon ways through representative institutions, then the legitimacy that consent provides is passed on through those institutions to the statutes themselves. ${ }^{121}$ Judges, where constitutions and statutes are unclear, or where they are acting pursuant to common law or equitable rules, might legitimate their decisions by conducting a contractarian thought-experiment to work out the rules that individuals would have agreed to had their consent been obtained in advance. ${ }^{122}$ Legitimate and ethical laws are those laws that plausibly can be represented as the product of prior consent. Contractarian theorists differ over whether the consent to legal rules must be actual consent of real people, hypothetical consent of abstracted people, plausible consent of familiar types of people, or something else. ${ }^{123}$ But the basic insight of the contractarian approach, that the legitimacy of a law depends on its ability to attract consent, remains the same across all variants of the theory.

Concretely, a contractarian approaches the justification of legal rules by asking about the rules disinterested individuals who will be bound by a given rule would agree to in advance. Individuals are considered disinterested if they do not know how they would fare under the rules in any particular case. This sort of thought-experiment is the hallmark of all contractarian approaches, but contractarians differ on many specifics about how such inquiries are undertaken. ${ }^{124}$ The contractarian argument elaborated below will proceed by asking to which rules about asymmetric information disinterested people recognizable as current residents of the United States can plausibly be represented as having been willing to consent-in advance of any particular cases arising under the rules.

120. Not all law may be thought of in this way. Both the common law and equity, passed on from "time out of mind," get their authority not from being the product of a representative government but from being the embodiment of the authority of tradition. In my work, I have tried to show how much of common law and equity can also be seen as having a consent-based moral logic, which takes it out of the realm of tradition and into the more modern age of trial by reason.

121. This is an extremely abbreviated version of the argument that H.L.A. Hart makes. H.L.A. HART, THE CONCEPT OF LAW (1962). For Hart, the legitimacy of a legal system rests on the fact that substantive rules can be shown to have been enacted according to regular procedures which themselves have been agreed upon by the population subject to the substantive rules. At the heart of Hart's argument about legal legitimacy, then, is the consent of the governed. In making this argument, Hart shifted the legitimacy-conferring authority from the superior sovereign to the people, conceived as possessing rights to self-rule that they give up in part to a government devoted to acting in their interests.

122. This is the central argument of my book. See generally SCHEPPELE, supra note 19.

123. See Kim Lane Scheppele \& Jeremy Waldron, Contractarian Methods in Political and Legal Evaluation, 3 YALE J. L. \& HUMAN. 195, 199-206 (1991), for a further specification of the alternatives.

124. For a review of the alternatives, see $i d$. 
Several features of this approach, applying contractarian reasoning to the examination of insider trading laws, require justification. First, why develop an argument just about insider trading, or disclosure rules under asymmetric information more generally, without considering the rest of the legal context in which such rules will operate? Most constitutionalist contractarians focus on designing whole systems and never get as far as defining specific legal rules. ${ }^{125}$ These holistic approaches have virtues when one wants to design political regimes from scratch, but when an existing, reasonably democratic political system is already in place, such a system generates expectations that then provide the basis for design of more specific legal rules. "Piecemeal" contractarian arguments, those made in support of specific rules, are attractive both because they give more concrete arguments that can be used to direct actual policy and because an individual rule that can plausibly be represented on its own as the result of consent raises no questions about intermediate violations of consentbased standards in the process of enacting the rules. ${ }^{126}$

Second, why ask people about a rule in advance, rather than when a particular dispute arises in which they are engaged? Part of the reason for asking people ahead of time is practical: if you ask people engaged in a dispute which rules they wish to invoke, they will typically pick the rules that allow them to win in the current fight. And this would mean that a contractarian thoughtexperiment would simply reproduce the deadlock that made one want to turn to contractarianism in the first place. After all, if people could agree on the ground rules and how they are to be applied in the moment of dispute, they probably would not be in court having arguments about the rules. By asking people to choose a rule without reference to the particular interests of the parties in particular disputes, it is possible to detach the choice of rules from the outcomes in specific cases.

Fairness provides a second reason why contractarians want to ask people ahead of time to agree on rules to which they will be bound. To be fair, rules should be chosen in such a way that no one gets an outcome that she would find intolerable if she turns out to lose in the particular case. If a person finds herself in an intolerable position as the result of the operation of a particular regime of rules, then it is hard to tell a contractarian story about why those rules would have been chosen. Asking people before they know how they will fare under the rules in specific cases or before they know what situations they will be in encourages them to imagine the worst that could happen to them under alternative rules and to choose the rules that would avoid intolerable outcomes.

125. See, e.g., RAWLS, supra note 118 (in which he shows concern for designing the basic institutions of a society and does not go so far as to elaborate what should be done in any concrete cases).

126. For a more extensive argument on this point, see Scheppele \& Waldron, supra note 123, at 20610. The general point is that consent to an entire system may include specific provisions to which there would be no consent if they were evaluated on their own. Enacting these first, therefore, would generate a situation in which there would be no intermediate consent to the evolving legal system. Piecemeal evaluation, looking at each rule one at a time, avoids this problem. 
This protection for the disadvantaged is one of the key moral components of modern contractarian thought.

Finally, why should the parties doing the choosing be imagined to be like current residents of the United States? Most contractarian theorists, John Rawls for example, imagine ideal consenters who do not look recognizably like people situated in any particular historical or cultural context. ${ }^{127}$ And for some very abstract problems in moral philosophy, like designing the basic institutions of a consent-based political regime in the first place, this may be a quite appropriate stance to take. But when one is constructing a thought-experiment about specific legal rules in a legal system already fully shaped, a current historical and cultural context would have to already exist in order for the thought-experiment to make sense. For rules to be justifiable to people already located in a particular institutional context, the rules must be justifiable to them in particular and not to some abstract population. If contractarian arguments are designed to be addressed to people like those who will actually be bound by these rules, political arguments that reproduce these justifications in a particular context are more likely to be met with a sense that those rules are, in fact, appropriate. In short, the closer a contractarian argument is to one that will persuade people who will in fact come under the jurisdiction of the chosen rules, the more likely such people are to consent when the time arises for the rules to be applied to them. Contractarian thought-experiments, then, become a rehearsal for political argument to be carried out in the larger community of democratic debate. ${ }^{128}$

\section{A. Obligations to Trading Partners}

A contractarian approach to the ethics of insider trading focuses on what has happened to those who are harmed. In addition, a contractarian focus on morality and fairness generally requires that we look into the distribution of benefits and losses, and not just their sum totals averaged over a particular population. Contractarianism, in general, proceeds from the perspective of those who stand to be harmed ${ }^{129}$ by any particular social arrangement, for it is their consent that is clearly most problematic in justifying the existing order of things. People who benefit from any particular social arrangement typically believe that the social arrangement in question is acceptable; those who lose, particularly those who lose time and time again, will probably be the most critical of existing

127. RAWLS, supra note 118 , at 136 .

128. See Scheppele \& Waldron, supra note 123, for elaborations of the argument in favor both of making the imagined consenters more sociologically realistic as well as of making the results of contractarian reasoning the basis for democratic deliberation.

129. One question that arises in insider trading regulation is whether there is any harm caused at all. Henry Manne's attack on insider trading proceeds from the assumption that there is no harm either to the allegedly defrauded traders (who would have bought or sold anyway) or to the market (which adjusts prices of stock so that other stockholders are not hurt by the insider trading, only by the information itself). See generally MANNE, supra note 1 . Clearly, those who were caught on the outside of an insider trade feel they were harmed, however. Whether this is enough to establish harm for the purposes of insider trading doctrine is another question. 
arrangements. The contractarian who is worried primarily about the consent of each individual to the rules of the game at issue will look first at whether a disadvantaged individual would have agreed to those rules in the first place. If those who lose under any particular rule might have had a good reason for agreeing in advance to abide by the operation of such a rule, the rule is justified, even if the individuals knew there were a chance that they would wind up where they did.

The stock market, like a number of other social institutions, is a mechanism for influencing the distribution of wealth; experimental evidence about how people feel wealth would be fairly distributed is relevant to understanding Americans' reactions to the design of rules affecting the stock market. In experiments conducted by Norman Frolich, Joe Oppenheimer, and Cheryl Eavey, people were asked, in a situation where they did not know how they themselves would fare, to choose among rules that offered: (1) strict equality, in which individuals' talents and abilities had nothing to do with the final distribution; (2) great inequalities that came with some chance for each individual to win great gains or to experience great losses as their talents and abilities dictated; or (3) some lesser degree of overall inequality in which both extremes were brought closer to the middle, where there are no huge winners but also no people who fell beneath a certain tolerable floor. The subjects in these studies, contemporary Americans, tended to choose the third option. ${ }^{130}$ Real individuals, it seems, are willing to trade some of their potential huge gains to get a guarantee that they will not fall below a certain level, but they are not so risk-averse or so committed to equality that they would sacrifice any possibility of gain to be guaranteed the maximum possible floor. In short, individuals like to take their chances within the context of institutions that provide a safety net, even if that means sacrificing the big gains they could potentially realize.

Results like these help to explain the moral attractiveness of the stock market itself. Individuals want to be able to take chances, as long as they are protected from catastrophe. The routine advice of financial consultants to investors, to invest only with money that they could afford to lose, is consistent with the view that people want a safe fallback position. Those individuals who invest everything they have raise questions of basic mental capacity or fraudulent inducement to invest, and at least some case law supports the view that such total and innocent investors have a remedy against those who advised them to invest without reasonable counselling. ${ }^{131}$ Banks and savings institutions are the social organizations designed to provide the safety net for preserving one's wealth; having limitations on the losses one can incur in these institutions is

130. See Norman Frolich, Joe A. Oppenheimer \& Cheryl Eavey, Laboratory Results on Rawls's Distributive Justice, 17 BRIT. J. POL. SCI. 1-22 (1987); Norman Frolich, Joe A. Oppenheimer \& Cheryl Eavey, Choice of Principles of Distributive Justice in Experimental Groups, 31 AM. J. POL. SCI. 606-36 (1987).

131. See, Chandler v. Butler, 284 S.W.2d 388 (Tex. Civ. App. 1955). For cases involving litigation against brokers by naive investors, see Berger v. Merrill Lynch, Pierce, Fenner \& Smith, 505 F. Supp. 192 (S.D.N.Y. 1981); Cant v. A.G. Becker \& Co., 374 F. Supp. 36 (N.D. Ill. 1974). 
crucial in meeting the concerns of contemporary Americans. ${ }^{132}$ The stock market would not need to provide guarantees against total loss of what one had invested as long as people were not encouraged to use the market as a home for all their worldly resources. One sort of safety net in the stock market, therefore, is the limitation of losses by the amounts people chose to invest. ${ }^{133}$

Since the stock market provides a place where people can take risks, and since empirical studies have shown that people prefer some risk to complete equality, a legal regime of full disclosure in which all share the benefits of knowledge available in the market is not likely to attract approval. Full disclosure appears in the case law on insider trading as the "equal information" theory described by Justice Powell in Chiarella. ${ }^{134}$ This option is not attractive in contractarian terms, however, because it would guarantee the sort of equality in the distribution of resources that most Americans do not accept, once they have been guaranteed a floor. The stock market has to allow for risk, for the playing out of one's talents and abilities, to meet the test of consent.

If, however, the stock market necessarily involves people taking risks with their resources, a contractarian should ask whether people would require constraints on the way that the market manages risks before its operation would be considered fair. Here, rational individuals could see that they may benefit from allowing inequality in the information with which people come to the market because they might be able to benefit from it. Knowledge is one of the ways in which talents and abilities manifest themselves. The experimental evidence demonstrates that people generally want to be able to use their talents and powers to try to gain advantage for themselves.

But people only like taking chances if they know that the chances are fair, that the deck is not stacked against them at the start. At this level, fairness requires that (1) individuals have a roughly calculable chance to win and that (2) they are playing on a level playing field. Let me take each of these points in turn.

1. A Roughly Calculable Chance to Win. A roughly calculable chance to win is crucial to the legitimacy of risk-based institutions because complete uncertainty about the risks involved cannot be dealt with rationally. For example, if you bought a ticket in the state lottery, you would be taking a risk. You may not know the precise parameters of this risk because you do not know how many other people are buying tickets, but you can work out roughly what the range of

132. Various forms of federal deposit insurance in financial institutions were designed to provide exactly this sort of safety net for the person whose wealth was entrusted to institutions that were supposed to minimize risk.

133. Note how this argument provides a persuasive contractarian argument for the limited liability of shareholders. If people can choose the levels of investment that reflect their willingness to take chances, then they can adjust the amount of wealth they keep in reserve to satisfy their needs for some level of security. If liability of shareholders were unlimited, then people would have to think about the stock market as a place where truly catastrophic losses were possible, and this would require changes in other rules of operation of the market if the institution were to meet a contractarian test of ethics.

134. Chiarella v. U.S., 445 U.S. 222 (1980). 
odds of winning is. Your attitude toward losing would be very different, however, if you later discovered that the lottery commission had removed your selected number from the set of numbers that could win without telling you. In the first case, the risk was within your imagined scope of probabilities; in the latter case, the probability that you could never win was not part of your reasonable calculation in entering the lottery. If you had known that your ticket would be withdrawn from contention, you would not have bought a ticket in the first place. In fact, you would have good reason to suspect the state lottery commission of fraud for doing this. The whole institution of a lottery presupposes that winning is possible under the right circumstances. If someone deliberately withholds that possibility, they have changed the risks you thought you were running and you would have good reason for believing the situation to be unfair, even if the exact level of risk were not clear when you started.

Now suppose the state lottery commission announced that there was a possibility that, on any given day, they would prevent your number from entering into the set of possible winning numbers. You might then have no chance to win on a particular day, but you still have the chance that this is one of the days in which your number might sneak through. The element of calculable risk has been restored, and the game can then emerge from the shadows of unfair conduct, though at a higher level of risk.

What does this tell us? It tells us that some sorts of risks are unacceptable, particularly when those risks involve secrets whose existence one does not even suspect. These sorts of secrets may be referred to as "deep secrets." Deep secrets are secrets whose very existence is hidden; one does not even know to look for information because one does not know the secret exists. Deep secrets present a hidden danger because the rational person does not take such knowledge, or even the possibility of such knowledge, into account.

Thinking in a contractarian framework, people will want to know when a secret may be deployed against them and they will want to be able to do something to protect themselves from the secret-keeping of others. They do not necessarily need to know the contents of the secret; they just need to know that the contents of the secret are possible. Secrets that could count as legitimate secrets, then, must be open to efforts at discovery or calculation to pass contractarian muster.

This is why the disclosure by the hypothetical lottery commission of the possibility that it will withhold the winning number some of the time makes all the difference in the acceptability of the risks people then run when they buy lottery tickets. The unthinkable has been converted to the thinkable and the risks people run with thinkable alternatives are much more likely to be judged as fair.

Such a transformation converts a "deep" secret to a "shallow" secret. A "shallow secret" is a secret whose existence is publicly known. With a shallow secret, one can tell whether a further search for information will be worth the effort and one can also tell what sort of effort one could undertake to find out the information. 
How do these observations translate into legal rules? Where secrets are deep, rational individuals would prefer a regime of full disclosure because this is the only way that they can protect themselves from the harm that would come from unseen dangers. Where secrets are shallow, however, individuals would prefer a regime in which secrets can be kept, because those from whom the secrets will be hidden will be able to take preventative measures to ward off the harms of secrecy.

In general, the common law of fraud distinguishes between deep and shallow secrets. In Simmons v. Evans ${ }^{135}$ the Simmons family was able to get out of the contract they had signed to buy a house from the Evans family because when the Simmons family moved in, they discovered that the local water company was in the habit of turning off the water supply every day between 7 p.m. and 7 a.m. Noting that no home buyer would be likely to suspect that the house had water only half of the time, the court found that the Evans's failure to disclose information made the agreement fatally flawed. The deep secret, deep because no one would think to look for the information, had to be disclosed. On the other hand, shallow secrets generally do not have to be disclosed. Courts have found that there is no obligation to disclose obvious defects, information in the public record, or things for which persons in the exercise of ordinary prudence would think to look. ${ }^{136}$

These observations could lead to the view that insider trading should be allowed as long as it were publicly known that insider traders were trading on the market. This is just like the lottery commission that announces that it will take your number out of the running on a particular day. Generally, one would prefer not to trade with insiders and not to buy lottery tickets on the day in which no award is given. But this can be seen as a risk like any other that someone may decide to run. The practice of insider trading must be public if it is to be permitted at all, though it would clearly increase the riskiness of stock trades for all the noninsiders concerned.

There is, however, an important way in which insider trading is not like the lottery example. Lotteries are generally determined by chance and so all one needs to know are that the various possibilities that are built into the game in order to work out roughly what the boundaries of the risk are. Stock trades are strategic, however. That is, the investor attempts to determine what her trading partner knows, while her trading partner is trying to work out what the investor knows. In impersonal markets like stock exchanges, of course, negotiation goes on indirectly because buyers and sellers do not meet and try to read each other's signals. The only signal conveyed by the market is price and the traders must attempt to discern what various prices mean in terms of the knowledge embedded in the price. ${ }^{137}$ Because price is such a compact signal, one that may

135. 185 Tenn. 282, 206 S.W.2d 295 (1947).

136. For the empirical evidence, see SCHEPPELE, supra note 19, at 127-60.

137. See Friedrich A. Hayek, The Uses of Knowledge in Society, 35 AM. ECON. REV. 519 (1945), for a brilliant demonstration of the way in which markets condense a great deal of knowledge into a price. 
convey many meanings, it is easy to hide superior knowledge in a trade involving asymmetric information when the only information is the price of a stock, leaving one's trading partner completely unaware. Inside knowledge, because it is not easily conveyed in stock transactions, takes on some of the characteristics of a deep secret. There is nothing in the market transaction to convey that the buyer or seller is trading on the basis of superior information, as opposed to guessing on the basis of incomplete knowledge or making a wild and ignorant trade. Since fluctuations in price can mean any of those things, the inside trader can hide his privileged position, though his identity, if one could ascertain it, might give him away. The fact that trading with an insider will have aspects of a deep secret makes it particularly suspect. While it may be possible to calculate the risks of trading with an insider, it is impossible to determine from impersonal exchanges whether one's trading partner is an insider or not. If people want the opportunity to use their talents and abilities to gain advantages, then the similarity between deep secrets and insider trading will cause legitimacy problems on contractarian grounds.

2. The Level Playing Field. If insider trading were allowed, the fact of insider trading would be a shallow secret, but not all shallow secrets are created equal. The contents of some shallow secrets are much easier for some people to acquire than others. While shallow secrets would generally be acceptable to those deciding in advance on a series of ground rules for secret-keeping, such individuals would not want to permit particular shallow secrets where the secretkeeper could initially find information much more easily than could the target of the secret. As long as one thinks one might be the target of the secret rather than the secret-keeper, one would not approve of arrangements in which one were doomed from the start. In other words, shallow secrets would only be acceptable if all those who might find the information useful began on a level playing field. This does not mean that all parties require equal information; stock markets would be unlikely to work for long if all parties to a transaction had to be certified as having identical knowledge. But it does draw attention to enormous disparities in the costs of acquiring information in the first place. In this regard, an insider will always have a significant advantage.

Why is this? Knowledge is one of the most crucial resources in decisionmaking. Knowledge is an element of every aspect of a decision: One must know what the alternatives are, what the costs and benefits are and how they are to be evaluated, what you and others want, and how others are likely to estimate the same things you are trying to estimate. If an insider is gaining information as a result of working for a firm (whether as officer, director, employee, or contractor) or through a tie with someone who does, then he has much lower search costs than do those who must acquire information through concentrated effort. Even brokers who know an industry must engage in research at some costs to themselves. This research will be more costly than discovering the 
information by working for the firm or being related to someone who does. ${ }^{138}$ An insider has lower search costs for information than others who must engage in efforts to learn the information, and this disparity in search costs makes the playing field no longer level. Since inequality in access to knowledge has a tendency to produce inequalities in everything else down the line, it is important to ask what sorts of inequalities in access to knowledge people will be willing to tolerate.

To understand this, let us modify our lottery example. Suppose that the lottery were run so that it were possible for some people to figure out which numbers would win by doing a sophisticated kind of research. In this system, there is a lottery master who controls the relevant parameters of the game. People who have been watching the lottery master for some time and know his habits can guess better than others which numbers to bet. It takes a big investment of time and energy to determine the habits of the lottery master, but a specialized group of consultants exists to provide the information to anyone who will pay them a fee. A contractarian will see no problem with this system because any potential player can either do the research herself or pay for someone else's efforts at finding out the information. There may be some disparities in the costs of acquiring information, but only very large disparities present a level-playing-field problem. Information in a system like this revised lottery is still open to efforts at discovery, and for the people who do not have the time to gather it, information is for sale. ${ }^{139}$

Suppose, however, that the lottery master could himself bet on the lottery. Since he controlled the game, he, of course, would always win. Even if others also happened to bet on the winning number, their gains would be diminished by the lottery master's share of the winnings. One can see that this would generate a lot of grumbling among the players, even if they were told in advance about the practice. There would always be someone with superior access to information who would always win. And while all the players would face an equal chance of coming up against the lottery master, the pairwise comparison of the lottery master and any particular player would always reveal radical inequalities that could never be remedied no matter how hard a player tried. The game would not be played on a level playing field. All the players would surely agree that the lottery master should not be allowed to play. The lottery master may vote for such a system, but only if he knew he would never have to be an ordinary player.

138. Brokers may cultivate social ties explicitly for the purpose of gaining information. As long as other brokers could do the same thing, there would be no problem with information passed on this way. When information flows through channels that are not open to others, however, it provides privileged access to those who learn at low cost through particularistic ties. The ordinary-language conception of an "insider" captures this privilege of access.

139. The equality argument developed here would, of course, apply to radical inequalities of other forms of property that would keep people from operating on a level playing field. This argument assumes that people investing in the stock market have enough money to pay for advice. 
Here again, equitable rules used in common law cases generally support the view that radical inequalities in social positions make suspect any agreement reached in their shadows. Many of the cases outlined in Part II of this article, where courts invoked equitable rules about fair dealing, found secrets to be illegitimate. This happened in cases where the two parties to a transaction were not roughly equally situated in the search costs they faced to find the information. One example was insurance contracts, where information about the insured is almost always more readily available to the insured than to the insurer. ${ }^{140}$ Another set of cases involved "special confidence," where one party's disability turned into another person's obligation to disclose information. ${ }^{141}$ In these cases, and in others, courts have long looked to see whether the secret-keeper had privileged access to information. In fact, even the cases about obvious and latent defects can be seen as representing a commitment of the law to equalize the costs of acquiring information because sellers who are in possession of a good with hidden defects is quite likely to have an easier time finding out about the defect than the prospective buyer who has no experience with the good in question. ${ }^{142}$ Where the secret-keeper and the target of the secret are not roughly equal in their abilities and opportunities to acquire the information, the existing law in torts and in contracts requires disclosure.

Equal access to information is the moral concept on which a prohibition on insider trading would be grounded. When one person has special knowledge and nonetheless trades with those who do not, the offense is not just that a secret is kept. The offense lies in the fact that the secret is withheld under conditions in which those with whom the secret-keeper trades cannot discover the information as easily (or, as Justice Blackmun pointed out in his dissent in Chiarella ${ }^{143}$ as legally) as those who have the secret information. The target of the secret and the secret-keeper do not have equal access to information, and that is the problem.

Consider the following hypothetical. If an insider were to trade with another insider, few would have moral qualms about the transaction. Under those circumstances, the two parties to the deal would be on equal footing; such equality of access to information underwrites the moral argument about secretkeeping. But the contractarian argument reveals what is wrong when insiders trade with those who do not have access to knowledge equal to theirs (not equal knowledge), particularly where the insiders trade using deep secrets. People would not agree to be part of a system where their disadvantage in access to knowledge could be turned into disadvantages in the distribution of other resources. They might be willing to take their chances on a system that required them to work as hard as anyone else at acquiring this knowledge, but they would

140. See supra text accompanying note 43.

141. See supra notes $39-41$ and accompanying text (special confidence case).

142. For a more complete argument to this effect, with many more examples, see SCHEPPELE, supra note 19 , at $111-78$.

143. Chiarella v. U.S., 445 U.S. 222, 245 (1980) (Blackmun, J., dissenting). 
not be willing to enter into transactions with people who are clearly advantaged relative to them at the starting point. When insiders trade with people who are in no position, or a distinctly disadvantageous position, to acquire the information that the insiders now want to use, the insiders should have an obligation to disclose the information or refrain from trading with these unequal trading partners.

This obligation should extend not just to those unproblematically thought to be insiders, like officers and directors employed by a particular firm, but also to anyone whose position gives them special access to knowledge that others cannot acquire. In the complicated world of corporate transactions, an insider should be considered to be any person whose position allows access to information unavailable to those with whom the insider is interacting. This does not mean that all traders must have equal information; rather, all traders should face roughly equal search costs in locating relevant information. Without such a level playing field at the start, it is unlikely that rational consenters would agree to such rules in advance. After all, why should one sign onto a system in which one may be permanently disadvantaged? It is the structural imbalance in access to information, as Justice Blackmun started to argue in Chiarella, that gives rise to the duty to disclose. ${ }^{144}$ This argument is grounded not only in existing equitable rules about fair dealing that courts have long invoked in determining fraud, but also in contractarian ethics.

\section{B. Obligations to Fellow Secret-Keepers}

So far, this article has assumed that the only question one need ask in determining whether disclosure of secrets should be required is whether one has some obligation to disclose secrets to one's trading partner. But this question does not exhaust the potential ethical arguments about secret-keeping. Secrets have enormous importance not just when they are used in gaining strategic advantage over others who have less knowledge, but also when they are used to unite people whose common knowledge is a critical feature of their relationship. In moving on to examining the obligations one may have to those from whom one learns secrets, misappropriation theory and its alternatives become important.

Each of us constructs the social world around us by disclosing special information to those who are close to us and by hiding that information from those who are not so close. Invisible boundaries in the social world are constructed by these small universes of shared knowledge. Sharing knowledge is one of the ways in which each of us creates a social space for ourselves, so it matters to each of us that we have the ability to make claims on others to keep our secrets and not to use against us knowledge gained from us while in a position of trust. While sharing of knowledge happens in all aspects of life, one can see these networks formed by shared knowledge quite easily in business

144. Id. at 251. 
where, as Oliver Williamson has noted, organizations can be seen simply as dense concentrations of shared knowledge. ${ }^{145}$

Since shared knowledge is so important, one can imagine that people trying to construct a binding social contract would want to preserve some protection for secrets that may be initiated by one person and passed on to another. Here again, the contractarian thought-experiment requires us to put ourselves in the position of each of the actors in this situation and to focus on what the potential losses are to each. Those who reveal secrets to others would not want to be exploited by having those secrets used to their detriment. The people who receive such information may want to use it for personal gain, however, and would prefer to be able to use the secrets freely. The losses that would be incurred if one could not use secret information are, in the words of economists, "opportunity costs," the costs of opportunities foregone, rather than losses from one's baseline position. Since empirical evidence about contemporary Americans demonstrates that people feel that losses from the status quo are much worse than losses from an imaginary ideal state, economic arguments notwithstanding, opportunity costs are not as important in estimating well-being as are the costs of losses from one's current position. ${ }^{146}$

Therefore, any loss from one's current position would play a larger role in designing contractarian rules than would losses in hypothetical opportunities. As a result, people would favor the rule providing that the information they disclose to others is protected instead of one that would allow them to gain at someone else's expense. Rational consenters would, therefore, opt for a set of rules that allows secret-sharers to enforce promises of confidentiality against those to whom they reveal the secrets and who further reveal or use the secrets for their own benefit. But such promises should be negotiated explicitly so that the recipients of secrets are not unilaterally bound by the preferences of others, and there is a clear expectation about what knowledge is to be protected.

In insider trading cases, however, the "persons" we are imagining may not be natural persons, but may instead be corporate actors or "juristic persons." So far, this argument assumes that corporate actors have much the same motivations and moral claims as natural persons. Discussions about insider trading often emphasize that the information used by insider traders is the property of the organization, where property is seen as having been developed, paid for, and currently owned by the corporation. ${ }^{147}$ In privacy cases, since information arguably is the product of one's investment in oneself, one might use a property rationale to justify allowing a natural person to keep information confidential.

But an argument from autonomy is a stronger one in such cases. An autonomy argument would emphasize the importance of personal information in grounding one's sense of oneself as an independent agent. Since corporations

145. WILLIAMSON, supra note 45.

146. See, e.g., Daniel Kahineman, Paul Slovic \& Amos TVersky, Judgment Under UNCERTAINTY: HEURISTICS AND BIASES (1982) (collected essays).

147. See supra notes 63-70 and accompanying text (discussion of misappropriation cases). 
have no such psychological requirements, the extension of such arguments to them is problematic. ${ }^{148}$ Therefore, corporations can make fewer demands on the autonomy of their employees and agents than can natural persons, and any agreement that knowledge may be used to bind someone in this way must be made explicit in advance. ${ }^{149}$

The argument that explicitly negotiated promises should be enforceable is quite similar to those that courts have advanced in deciding "public disclosure of private facts" privacy cases. Those who have acquired information from a person under a pledge of confidentiality can be found liable for disclosing that information to the detriment of the secret-keeper. For example, in Doe $v$. $R o e,{ }^{150}$ a psychiatrist published a detailed, only thinly disguised, life history of one of her former clients. Finding that a promise of confidentiality had been breached, the court found the doctor liable for invasion of privacy. In Horne v. Patton, ${ }^{151}$ a doctor was found to have invaded the privacy of a patient when the doctor revealed aspects of the patient's medical condition to the patient's employer.

In the insider trading cases, one must consider obligations that inside traders have to those from whom they learned the secrets. Since the special knowledge that insiders have is, by definition, knowledge available only within a particular social setting that is not available outside that setting, such knowledge cannot be used for personal gain by the inside trader without violating the expectations of others in that setting. ${ }^{152}$ Since a contractarian view should consider all those who might be harmed by any particular conduct, this potential harm of disclosure to those who share the inside information must be considered.

148. Many analogies have been drawn between corporations and individuals, analogies aimed at extending individual rights to corporations. Psychological arguments about autonomy, for example, may sound rather like arguments about a unique corporate culture which preserves a corporation as a distinctive entity. But several hundred years of Enlightenment philosophy is basically unified on this: Individuals are morally special in the sense that their autonomy and dignity are different sorts of claims, more than claims for the autonomy and dignity of corporate formations. Preserving a strong version of individual rights requires that individuals be able to opt out of collective formations that they find oppressive. This would mean giving fewer rights to corporations than to individuals in order to preserve this balance.

149. I developed a similar argument about explicit promises in Legal Secrets in the context of discussing privacy cases. But in Legal Secrets, I took the contrary view on the question of the similarity of natural and juristic persons, assuming that information about persons in the privacy context and information about corporations in the trade secret context were functionally equivalent. See SCHEPPELE, supra note 19 , at $181-90$.

150. 400 N.Y.S.2d 668 (N.Y. Sup. Ct. 1977).

151. 287 So.2d 824 (Ala. 1973).

152. Some social settings may generate expectations that everyone in the group may use whatever they learn in the group for personal gain. One might expect social groups of investment bankers and stockbrokers, for example, to act in this way. If there are no expectations of confidentiality in a group, then there is no offense to such expectations if the information is used outside the group. But where there are understandings about confidentiality, as is more typically the case with groups sharing nonpublic information, disclosure outside the group would in fact violate important expectations that might ground liability for insider trading. 
Such concerns require us to modify the "misappropriation" theory of insider trading urged by the Second Circuit, in cases like U.S. v. Newman ${ }^{153}$ and SEC v. Materia, ${ }^{154}$ to meet contractarian concerns. As we have seen in this discussion, the wrong in insider trading consists of the willful misappropriation of information that is explicitly entrusted, for a specified purposes, by a company to the insider. Using the information for personal gain is misappropriation because the use violates the explicit terms of the agreements under which the information was conveyed. As Chief Justice Burger said in his dissent in Chiarella, in these cases the defendant can be said to have "misappropriated-stole to put it bluntly-valuable nonpublic information entrusted to him in the utmost confidence."155 Misappropriation causes harm to those who trusted the insider, either by denying them the profits from the use of the information or, more frequently, by damaging the reputation for trustworthiness of the company, as happened in Chiarella and Carpenter.

A contractarian argument would favor a set of rules in which individuals or firms could bargain for and enforce explicit promises of confidentiality, with three important exceptions. First, the worry about "safety nets" that is a prominent feature of modern contractarian arguments would still be relevant. Some secrets, collectively created and collectively enforced, still do severe damage to people outside the group maintaining the secret. Such secrets, because of the extent of the harm that they cause to those left out of the secrets, ought to be disclosed to those who stand to be hurt by them, regardless of the promises violated by such disclosures. Consider, for example, the Equity Funding scandal that was the subject of Dirks. ${ }^{156}$ This secret about the ongoing fraud should have been disclosed, even though the person doing the disclosing was an insider subject to promises of confidentiality. Investors stood to be seriously hurt by the Equity Funding scandal because the fraud substantially affected the value of every investment in Equity Funding. If there was an offense in Dirks, it was that not all those affected in the same way received the same notification, and so some of those who faced great losses were able to get out before their fellow sufferers were alerted to the danger. By the time the information was made public, it was too late for those who had not received early notification to protect themselves. Selective disclosure of critical information of great importance to people's welfare is probably better than no disclosure, but a rational consenter would insist on rules that gave all potential sufferers the same information at as nearly the same time as possible.

The second qualification to the contractarian case for supporting a breach of confidence theory has to do with the way in which harm must be demonstrated by the original secret-holder to be enforceable in a misappropriation claim. Under current law, criminal prosecutions are often mounted under a theory of

153. 664 F.2d 12 (2d Cir. 1981).

154. 745 F.2d 197 (2d Cir. 1984).

155. Chiarella v. U.S., 445 U.S. 222, 245 (1980) (Burger, C.J., dissenting).

156. Dirks v. SEC, 463 U.S. 646 (1983). 
misappropriation regardless of whether the allegedly offended party is hurt or not. In a case like United States $v$. Reed, ${ }^{157}$ Thomas Reed clearly would not have wanted his son to go to jail for acting on a secret he had told him. Without a concrete demonstration that his father was injured, the younger Reed should not have been prosecuted on the basis of the fiction that his father was the main victim of his dealings. The injury to the father was not that he was abused by breach of confidence, but rather that he had led his son into temptation. If young Reed violated insider trading rules, it was because he traded with people who could not have known this information, not because he hurt his father.

Finally, the misappropriation theory, by virtue of tracing out who owns the information and how it is being exploited, has a tendency to track criminal activity through friendship networks. This, as noted above, ${ }^{158}$ is a very intrusive use of the federal criminal enforcement powers. If one person shares a secret with another with the expectation of creating a friendship or other relationship of trust, the violation of that trust by the tippee should not echo back through the chain of disclosure implicating everyone in its trail. If someone entrusted with a secret uses it for his own benefit, then he and he alone should pay for it unless others act in conspiracy with him. But trusting someone with information that one has not used for personal gain should not be made into an offense because the person to whom one gave the information then used it illegally.

The arguments in this Part and the arguments about equality of access to information in the last Part are strongly connected. If someone, by virtue of ties of friendship, common employment, or contract, learns information that would be relevant to a stock trade, then he cannot use it in trades with others who cannot have learned such information. Particularistic ties, like those that arise through friendship, employment, or contract, are, by definition, not open to everyone. Not everyone could be in such a position to acquire information. Inequality of access is the primary reason why information learned in such particularistic ways should not be used in trades against those who are ignorant. The insider who knows a secret knows it through ties that both provide the information and reduce the costs of acquiring it. Insiders have much cheaper search costs precisely because their connections give them better access to information. Because of the combined effects of these privileges, insiders should be prevented from trading with those who are much less privileged.

As we have seen in this Part, then, a contractarian argument supports an equal access theory when an insider uses inside information against ignorant trading partners, and a modified enforceable promise theory when information is disclosed outside of circles of confidence. In both cases, the potential for severe losses triggers full disclosure. In cases where full disclosure to an ignorant trading partner would violate the promises of confidentiality that the inside trader has made to others, the insider should refrain both from trading against

157. 601 F. Supp. 685 (S.D.N.Y.), rev'd on other grounds, 773 F.2d 477 (2d Cir. 1985).

158. See supra text accompanying note 109. 
ignorant partners and from disclosing the information in violation of promises. This "disclose or abstain" rule is quite close to the rule adopted by the Securities and Exchange Commission in its landmark case In re Cady, Roberts and Co. ${ }^{159}$ and by the Second Circuit in its important ruling in SEC v. Texas Gulf Sulphur Co. ${ }^{160}$ The Supreme Court reinterpreted Cady to assimilate it to a theory of fiduciary duties. ${ }^{161}$ But the Cady and Texas Gulf Sulphur line of cases settles on a formula by which traders must disclose the information they have gained in ways others could not, or refrain from trading with others who do not have equal access to information. Contractarian arguments seem to duplicate some elements of insider trading doctrine, though not for the reasons that the Supreme Court has outlined.

\section{$\mathrm{V}$}

\section{CONTRACTARIAN EVAluation OF RECENT Doctrinal DEVELOPMENTS}

In 1986, Ira Waldbaum, president of the Waldbaum supermarket company and head of the family that together owned fifty-one percent of the company's shares, agreed to sell Waldbaum to A\&P. In this deal, Ira sold his controlling block of Waldbaum shares to A\&P for about double their current market price. Two days after agreeing to this sale, Ira told three of his children, his sister (Shirley Witkin) and his nephew (Robert Karin) about the deal, offering to tender their shares with his own to simplify the transactions. All were told that the information about the sale was to be kept highly confidential. Shirley Witkin, however, told her daughter (Susan Loeb), warning her not to tell anyone except her husband. Daughter Susan told the news to her husband Keith Loeb, telling him not to tell anyone because "it could possibly ruin the sale." next morning, Keith called his broker, Robert Chestman, and told Chestman that he had "some definite, some accurate information"163 about the sale of the Waldbaum grocery chain. Chestman knew that Loeb's wife was a member of the Waldbaum family, and so he was able to surmise that the information came on good authority. But Chestman declined, when asked, to provide advice to Keith on what he should do about the matter. Later that morning, Chestman bought 3000 shares of Waldbaum stock for his own account, and shortly after that, he bought 8000 shares for his clients' discretionary accounts. Prices ranged between $\$ 25.75$ and \$26 for Chestman's purchases. Later that day, Keith called Chestman again and asked him again what to do. Chestman again said that he could not advise Keith "in a situation like this" but added that on the basis of research Chestman himself had done, he thought that Waldbaum would make a good investment. Keith then bought 1000 shares of Waldbaum stock. The next day,

159. 40 S.E.C. 907 (1961).

160. 401 F.2d 833 (1968) (en banc).

161. Chiarella, 445 U.S. at 227 n.8; Dirks v. SEC, 463 U.S. $646,653-54$ (1982).

162. Chestman II, 947 F.2d 551, 555 (2d Cir. 1991) (en banc), cert. denied, 112 S.Ct. 1759 (1992).

163. Id. 
when news of the tender offer was publicly announced, stock prices rose to $\$ 49$ per share. Charged with insider trading, Keith Loeb agreed to disgorge his profits and pay a fine. Chestman was charged with and convicted of multiple criminal counts of insider trading, fraudulent trading in connection with a tender offer (a violation of Rule $14 \mathrm{e}-3^{164}$ ), mail fraud, and perjury. Though Chestman's story about what happened differed substantially from this rendering at trial, the jury that convicted him on all counts did not believe his version. A panel of the Second Circuit Court of Appeals reversed all the convictions, ${ }^{165}$ but in the rehearing the en banc court chose to deviate from the panel's decision by reversing the trial court's convictions under Rule $10 \mathrm{~b}-5$ and mail fraud, while upholding the convictions under Rule $14 \mathrm{e}-3 .{ }^{166}$ I will not discuss the court's decision on the Rule 14e-3 counts, but will concentrate on the Rule 10b-5 claim, on which the court split nearly down the middle.

Judge Meskill, writing for the majority in votes if not in reasoning, reviewed the various theories on which Chestman's criminal conviction might be based. Under the traditional theory of fiduciary duties, a finding of fraud is predicated on a traceable breach of a duty, but a fiduciary duty cannot be created by the mere possession of information not in the possession of another. Under the misappropriation theory, not yet approved by the Supreme Court but in clear favor in the Second Circuit, a person can be found guilty of fraud when he uses the information obtained through an employment relationship for his own personal benefit. The two theories merge, Judge Meskill argued, over the idea of a "temporary insider," one who owes a duty to his employer not to use information but who then uses it anyway in breach of a fiduciary duty. The difficulty in evaluating the charges against Robert Chestman, Judge Meskill wrote, was that the relevant breach of duty by an insider here did not arise in the context of an employment relationship, but instead in the context of a family relationship. ${ }^{167}$ And here, the various theories seemed to provide Judge Meskill with little help.

In employment relationships, Judge Meskill argued, duties are clearer, the boundaries of legitimate disclosure are more firmly fixed, and fiduciary relationships are more clearly distinguishable from nonfiduciary ones. In families, however, the existence of fiduciary relationships cannot be presumed and may be difficult to determine. Worries about due process and fair notice may arise if a court were to find certain family relationships sufficient to ground claims of breach of duty while other family relationships could not sustain such claims. Fiduciary relationships, Judge Meskill argued, require an aspect of dominance, or reliance by the party doing the trusting on the party being

164. 15 U.S.C. $\$ 78 \mathrm{n}(\mathrm{e})$ is the enabling statute; 17 C.F.R. $\$ 240.14 \mathrm{e}-3$ is the relevant rule.

165. United States v. Chestman, 903 F.2d 75 (2d Cir. 1990).

166. Chestman II, 947 F.2d at 571. The en banc court did not hear an appeal from the perjury charge.

167. Id. 
trusted. ${ }^{168}$ But in family relationships, disclosures are made gratuitously in contexts where there is no reliance or presumed superiority of one party to another and they occur without explicit negotiations about how the information in question is to be used. In the present case, Judge Meskill found that Keith Loeb did not have a fiduciary relationship with the Waldbaum family because there was no evidence that the family routinely talked about the family business with Keith, because he had not been brought into the family circle, because his wife communicated this important information to him gratuitously even though no one else expected or wanted her to tell him, and because there was no special influence or reliance between Keith Loeb and the Waldbaums. ${ }^{169}$ The court also found that there was no fiduciary relationship between Keith and Susan Loeb because she told him the information without being prompted and without first extracting a promise of confidentiality. Since Keith was not in a fiduciary relationship with his in-laws or his wife, he breached no duty and, therefore, Chestman could breach no duty derivatively. ${ }^{170}$

Judge Winter, in dissent, argued that Chestman's convictions on Rule 10b-5 should have been upheld under both the fiduciary duty theory and the misappropriation theory. ${ }^{171}$ On the fiduciary theory, Judge Winter pointed out that in family-controlled corporations like Waldbaum, confidential information about the business is a routine part of family conversations. To maintain informal family relationships so that such conversations could go on, a duty not to disclose must be presumed in such cases. Judge Winter would have found that Keith Loeb owed a duty to the Waldbaum family, a duty breached in telling Chestman, who then exploited this breach by trading on the inside information. ${ }^{172}$

Judge Winter's dissent was heavily influenced by the law-and-economics writing on the matter. He noted that information is one of the most valuable commodities in securities markets and those who have invested in producing it should be able to reap profits from their efforts in acquiring it, as long as the means of acquiring the information did not amount to theft. Misappropriation theory, according to Judge Winter ${ }^{173}$ has a solid policy argument behind it; the theory ensures that information important to markets continues to be produced by providing protection for such investments and by allowing those who produce information to profit from it. Keith Loeb's activities, however, amounted to theft of family property. The advance purchases made on this inside information by Chestman threatened to release the information to the public, and such a release

168. Id.

169. Id. at 570-71.

170. While most husbands and wives would probably be alarmed to learn that they are not in a fiduciary relationship, Keith and Susan were no doubt relieved by this finding because it meant that Keith's broker could not be found guilty of insider trading and that Keith, had he been charged, would not have been found guilty either.

171. Id. at $571,579-80$.

172. Id. at 579.

173. Id. at 578 . 
would have harmed the family. Under both theories, then, Judge Winter would have upheld Chestman's convictions under Rule 10b-5.

What would a contractarian say about this case? First, a contractarian would want to consider the obligations to the trading partners with whom Chestman dealt through the anonymity of a stock exchange. Existing nonfamily shareholders could not know the information that Chestman knew because this information was kept solely within the Waldbaum family. Chestman's access to the information was clearly superior to the access any nonfamily shareholder would have ${ }^{174}$ because Chestman was in a position to hear stock information from the husband of a Waldbaum family member. In fact, this information was superior to the knowledge that any other broker not connected to the Waldbaum family would have. This special access created a structural inequality, which should trigger a requirement of disclosure. Chestman, because of his inside connections, simply had lower costs of acquiring this information than anyone else in his position. He learned information because he was Keith Loeb's broker, and Loeb needed to go through Chestman to effect his purchase in the first place.

Chestman had superior access to information because of the connections he had, but a contractarian analysis does not require, as does the current Supreme Court theory, that all possible fiduciary relationships be scanned for specific duties owed to specific people. Chestman's duty on the contractarian account would be first to those with whom he was trading, shareholders who could not yet know what he knew. And then, secondarily, a contractarian would ask whether Chestman himself violated any confidences to make his deals.

Note that this analysis does not require that all parties to the trade have equal information at the time of the transaction. If Chestman had bought stock from Shirley Witkin, Keith's mother-in-law, the structural inequality would not be present. ${ }^{175}$ Ms. Witkin would have, through intimate family ties, the same access to information that Chestman had. Even if Ms. Witkin did not actually know about the tender offer at the time she sold her stock, Chestman would not have been in a position of structural inequality with her that would require disclosure. Since, however, trades through markets strip away the individualizing features from particular traders, further investigation would be needed to uncover whether the parties who bought and sold particular shares through

174. The only other shareholders who could know were the family members, to whom an obligation to disclose or abstain would also apply from the contractarian theory. If Chestman had traded with one of the Waldbaums, both being insiders, the contractarian theory would have no problems with this trade on inequality grounds.

175. Of course, Shirley would have no good reason to sell, knowing as she did that the price was going up. If she did want to sell, it must be either because she was desperate to meet a deadline or because she had made a mistake. Since all insiders with accurate knowledge will have incentives to buy or sell in the same direction, actual trades between insiders are highly unlikely to occur in the real world. One can assume that if an insider is buying from someone willing to sell, the seller must also not be an insider. The example is useful, however, because it illustrates that the equal access theory does not prohibit all insider trading. Insiders trading with insiders does not offend against this theory, precisely because they are on equal footing. And the fact that such trades rarely occur should help us see why the trades that occur with asymmetric information are occurring because of the inequality. 
exchanges had equal access to the information on which they traded. The typical shareholder would not have such superior "inside" access and so the possessor of inside information should not count on the fluke of two insiders trading in opposite directions on the basis of hidden knowledge in order to justify the use of inside information.

This does not exhaust the contractarian analysis, however. Consider the argument from enforceable promises to keep secrets. Here a contractarian would want to know whether there were understandings within the Waldbaum family. Did Ms. Witkin and her daughter and did Susan and Keith Loeb have understandings that business information would not be transmitted outside the family? Since implicit understandings of promise-making can restrict the abilities of people to act autonomously and in their own interests, anything short of an explicit agreement not to pass on the information should not ground criminal liability. In the context of family relationships, however, such explicit agreements are quite awkward to make. In longstanding relationships between natural persons, where a certain amount of trust has been established, it seems unnecessary to require that every individual disclosure of confidential information should be accompanied by a specific promise. The absence of an explicit prior promise in the disclosures from Ms. Witkin to Susan, and from Susan to Keith, could be viewed as evidence that the information was not confidential, but the absence of such promises may also be evidence that there was so much trust and confidence, and so much of an expectation of secrecy, that the explicit promise "went without saying." Relationships built on a sense of dailiness and trust are likely not to be accompanied by formal negotiations and specific promises. The "gratuitous" nature of the promise that Susan extracted from Keith, then, should probably be read more as a reminder of a preexisting understanding than as an attempt by Susan unilaterally to impose an obligation on Keith.

This argument would not apply in the corporate setting, however, since individuals have more limited obligations to act in the interests of their employers. In corporate settings, the duties of office must be made explicit to prevent the creation of a "total institution" where individuals have no life outside the office. ${ }^{176}$

Judge Meskill's analysis in Chestman fails to recognize how special access to information gives some traders an unfair advantage over others. In addition, the failure to recognize enforceable promises to keep information secret in contexts outside of employment contracts is likely to lead to a system where no one can be trusted in intimate relationships and where people must be on their guard in friendships and family relationships. Neither of Judge Meskill's arguments is likely to attract consent as a general proposition on the part of people who can imagine themselves on the losing end of these rules.

176. The concept of a total institution is explained in ERVING GOFFMAN, ASYLUMS 1-124 (1961). 


\section{VI \\ CONCLUSION}

This article has attempted to show why a theory of insider trading based solely on fiduciary duties, as currently used by the U.S. Supreme Court, is inadequate to regulate insider trading. Not only does the theory fail to acknowledge the equitable rules about fraud that have long been in use in U.S. courts to deal with very similar cases involving disclosure of information, but it also fails to acknowledge the more complicated and anonymous relationships that now characterize corporate America.

This article proposes an argument from contractarian ethics to ground an alternative vision of insider trading. Contractarian ethics captures much of the spirit of equitable rules about disclosure, but puts those rules on a more coherent and rational footing than previous analyses have done. A theory of equal access to information, in contrast to a theory of equal information, would be most likely to attract the consent of contemporary residents of the United States. A complementary theory of enforceable promises could supplement the equal access theory to deal with cases where the knowledge in question has damaged those who disclosed the information to the inside trader in the first place. 
